\title{
MICROVERTEBRATE CONCENTRATIONS IN PEDOGENIC NODULE CONGLOMERATES: RECOGNIZING THE ROCKS AND RECOVERING AND INTERPRETING THE FOSSILS
}

\author{
J. A. Schiebout, Suyin Ting, and J. T. Sankey
}

ABSTRACT

Pedogenic carbonate nodule concentrations are an under-utilized resource for the recovery of terrestrial microvertebrate faunas. They have proved productive in Late Cretaceous, late Paleocene, and Miocene rocks of Texas and Louisiana. These concentrations of nodules and fossils form at channel bases and by erosion of soils in interfluves. Treatment of large samples of the conglomerates with dilute acetic acid allows recovery of delicate specimens, with teeth of small vertebrates being the main identifiable component. Geologists and paleontologists should be alert to these rocks' potential, because relatively small lenses, which can be found in gullies and stream banks even in heavily vegetated areas such as western Louisiana, may yield significant fossil faunas.

J.A. Schiebout and Suyin Ting, Museum of Natural Science, Louisiana State University, Baton Rouge, LA 70803, USA. Correspondence should be directed to Schiebout.

J.T. Sankey, Department of Geology and Geophysics, Louisiana State University, Baton Rouge, LA 70803, USA

Keywords: microvertebrates, conglomerates, acid treatment, taphonomy, pedogenic nodules

Submission: 20 September 1997

Acceptance: 28 July 1998

Copyright: Paleontological Society, 1 August 1998

http://palaeo-electronica.org/1998 2/schiebout/issue2.htm

\section{INTRODUCTION}

Concentrations of pedogenic nodules do not look promising as fossil sources, but at least in the US Gulf Coast, have proved very productive. They have been especially valuable in a recent large-scale project involving the first sizable Miocene vertebrate faunas from Louisiana. We have explored a variety of methods for efficiently extracting delicate teeth (Figure 1), often smaller than one $\mathrm{mm}$ in crown maximum diameter, from rocks that look a lot like concrete curbing, and have developed methods suitable to small lab spaces and low manpower.

Earlier work predisposed Schiebout in 1993 to recognize a layer of conglomerate containing pedogenic nodules, in a manmade exposure at Fort Polk in western Louisiana (Figure 2), as a significant paleontological opportunity. She had been called to the site to examine a recently found, nodule-encrusted merychippine horse partial mandible (Figure 3). The layer of nodule-rich conglomerate at Fort Polk was the first of seven sites which have yielded over 3,000 catalogued fossils since 1993. Schiebout's 
work on such rocks in Big Bend National Park, Texas, prepared her to recognize other fossil-rich conglomerates. Fossil hunting had been ongoing in the Paleocene Black Peaks Formation in Big Bend for more than twenty years, but had yielded few vertebrates in the small size ranges when she began work in 1968. Small mammal teeth eroding from a lens of pedogenic nodules, when screened, added a small-mammal component to the late Paleocene of Big Bend (Figure 2 and Figure 4; Schiebout 1974, $\underline{1979}, 1981$; Schiebout et al. 1987; Schiebout et al. in press). Later surveying for screening sites in the Late Cretaceous to early Eocene of Big Bend in the 1980s revealed a layer of nodule-rich conglomerate in the Late Cretaceous Aguja Formation (Figure 5). Many shark, fish, lizard, dinosaur, and mammal teeth have been recovered through dissolution and screening from it and other Aguja Formation conglomerate horizons in its vicinity (Sankey 1995, 1996, 1997; Sankey and Schiebout 1997, Sankey 1998).

\section{MATERIALS AND METHODS}

Claude Hibbard (1949) standardized the process of bulk screening for vertebrate fossils from rocks that disaggregate in water by developing wooden boxes with screen bottoms and two partially screened sides, which could be placed in a stream and agitated to remove the mud (Figure 6). Acid treatment to remove calcium carbonate from nonmicroscopic vertebrate fossils is discussed in Rutsky et al. (1994). The unusual element of our procedures is the large-scale bulk screening of rocks that must be partially dissolved first.

Collecting in the field is more similar to micropaleontological sampling in which sediment samples are bagged for later treatment than to most methods of vertebrate paleontological collecting, except that the bags are much larger and several may be required even for a test sample of a site. We have used burlap bags (Figure 7 and Figure 8) and currently use woven plastic "burlap" bags and close them with duct tape (Figure 9). Some of the conglomerates are the hardest rocks in the area and require using an airless jackhammer and sledge hammer to detach pieces. In some of these cases, for example at Stonehenge Site (Figure 10) in the Fort Polk Miocene, a gasolinepowered jackhammer has been used to break up the rock for transport.

Current laboratory treatment of the Fort Polk Miocene conglomerates involves soaking pieces, usually between three and forty $\mathrm{cm}$ in diameter, in approximately $10 \%$ acetic acid to partially dissolve cement, releasing the fossils and nodules as a residue (Movie 1). Calcium carbonate, which is dissolved in weak acetic acid, is the main mineral in the nodules and in the cement holding the rock together. Teeth and bones are composed of apatite and are not dissolved. Sankey and students under her direction have experimented upon Cretaceous conglomerate from Big Bend, Texas, and concluded that up to $40 \%$ acetic acid can be used without harm to vertebrate teeth from these conglomerates, but a $10 \%$ concentration has been seen to cause erosion of dentine in a few instances on the Fort Polk Miocene specimens, so the largest of our dissolution operations continues at that level of acid concentration. 
Bulk acid lab procedure on the Louisiana Miocene rocks has undergone a process of refinement since 1993 as efforts to dissolve tons of rock in a cost- and time-efficient manner continue in small lab spaces with relatively little manpower. Heavy plastic 10gallon lidded storage boxes (Rubbermaid Rough Totes()) were used in an initial stage, which was supplanted by a method utilizing 85-gallon barrels (hazardous waste overbarrels) containing nets in frames to hold the rocks suspended in acid solution, which were lifted and handled with a hoist on wheels (Dooley et al. in press). This procedure is worth considering in some circumstances, but we have returned to using large numbers of 10-gallon lidded boxes, which are easier to handle for small to average-sized adults. They also offer a simple way to isolate and test small (less than $50 \mathrm{~kg}$.) initial samples, and use of them allows having as much rock in acid in an equivalent square footage as the large barrels do.

Currently, two people work four hours a week in the acid lab, handling 53 dissolving boxes. Approximately $10 \mathrm{~kg}$ portions of conglomerate are initially placed into each box and covered with $10 \%$ acetic acid. The amount disaggregated from Fort Polk last year with this method is $1,049 \mathrm{~kg}$. Boxes are screened on a three-week cycle of rotation, with sixteen usually being washed each week. They are moved on a trolley to the sink area where the large chunks of rocks are removed from the boxes by hand and stacked on the lids (Movie 2 and Movie 3 ). The residue in the boxes is washed in running water over two nested screens, a coarse (1-3 mm mesh opening) screen to remove large nodules and rock pieces, and a fine $(0.59 \mathrm{~mm}$ opening) screen (Movie 4 and Movie 5 ). Material caught on the coarse screen is returned to the acid, and the residue from the fine screen is spread in trays to dry at room temperature (Figure 11) or under heat lamps. When dry (Figure 12 and Figure 13), it is sorted under the microscope to pick out small fossils, mainly bone scrap and teeth. Schiebout's previous experimentation with heavy liquid techniques (sodium polytungstate) for chemical separation of fossils from screened residue from Big Bend, Texas, has suggested that visual picking for these rocks is equally efficient.

Spent acid solution (Movie 2) is poured into an 85-gallon waste barrel to await neutralization using sodium bicarbonate (Arm and Hammer@ brand baking soda) to raise the $\mathrm{pH}$ of the waste water to the EPA-required 5.5-7.0 range allowed for disposal. The amount of rock disaggregated for each liter of glacial acetic acid used, varies among the sites at Fort Polk because of such factors as the nodule size and degree of cementation of the rock. Kilograms dissolved per liter during the last year are: 1.0 for TVOR Site, 0.6 for Stonehenge Site, and 1.1 for DISC Site. Acid is purchased as glacial acetic in 55-gallon drums. Safety equipment routinely used in the bulk acid lab includes rubber gloves and goggles, and respirators which filter acid fumes and organics, worn during handling of the glacial acetic acid (Figure 14 and Figure 15).

The fossil specimens are stored in large gelatin capsules, so that individual fossils can be numbered, studied, and photographed (Figure 16). A pin is inserted through the cap end of the capsule and fixed so it cannot slide in or out, by a drop of acetone-soluble glue on the exterior of the pierced end of the capsule. The specimen number is written on the portion of the capsule containing the pin, and a tiny fossil is stuck to the pin point 
on a small piece of wax. The use of wax instead of glue allows shifting the fossil's orientation or removing it if necessary, for example, for SEM photography. In SEM photography, LEIT-C-PLAST, a plastic conductive carbon cement, is used to mount the fossils so they do not need to be coated.

\section{CARBONATE NODULE CONGLOMERATE FOSSIL SITES}

\section{Paleocene, Big Bend National Park, Texas}

Carbonate nodule concentrations in Big Bend yielded a significant portion of the fauna of the Paleocene Black Peaks Formation (Schiebout 1974). The Big Bend Paleocene site, Joe's Bonebed conglomerate, was a small lens of nodule-rich conglomerate (roughly $1 \mathrm{~m}$ across and $8 \mathrm{~cm}$ in maximum thickness), that was collected and wet screened as part of Schiebout's doctoral research. It was a muddy granule conglomerate (terminology of Folk 1968, p. 28, 29), rich in clay and lacking carbonate cement (Schiebout 1974). No acid dissolution was necessary for disaggregation. Instead, rock was warmed in an ordinary oven to dry it completely, soaked in the drycleaning fluid Varsol, and immersed in water. Water displaced the Varsol and broke the rock into its components. After screening, the residue was picked to yield small mammal teeth, including plesiadapoid primates, multituberculates, and insectivores (Schiebout 1974). Schiebout (1974, p. 41) concluded that the Joe's Bonebed deposit was formed by erosion on a floodplain, and did not involve addition of material from the large, through-going rivers of the region that were carrying considerable sand which would otherwise have been a more prominent component in the conglomerates.

\section{Cretaceous, Big Bend National Park, Texas}

Caliche nodule and limestone pebble conglomerates from the Late Cretaceous (Judithian Age) Upper Shale member, Aguja Formation of Big Bend National Park, Texas were acid processed from 1995-1998 at LSU. Material totaling approximately $1,630 \mathrm{~kg}$ from five conglomerate horizons, all within $20 \mathrm{~m}$ stratigraphically, was collected and processed, yielding terrestrial and marine vertebrates (Sankey 1998). Previously, these conglomerates were usually ignored by paleontologists as a source of fossils because of the difficulty in disaggregating them. Although Lehman (1985) noted conglomerates in many of his stratigraphic sections through the Aguja Formation, no one had attempted to disaggregate and screen them before the current project. The conglomerates (Figure 17 and Figure 18) are considered to be concentrates from the bases of channels deposited on a marshy coastal plain during the final regression of the western Interior Seaway in southern North America. Small fossil teeth and bones represent fish and sharks from the brackish marine environment, and salamanders, lizards, turtles, dinosaurs, and mammals, which, along with the nodules, represent erosion and reworking from terrestrial and freshwater habitats. Thirty-six vertebrate taxa have been identified (Sankey 1997; Sankey and Schiebout 1997, Sankey 1998). 


\section{Miocene, Fort Polk, Louisiana}

There are seven stratigraphically distinct localities at Fort Polk from which vertebratefossil-bearing conglomerate is being processed. The Discovery Site (DISC), is the stratigraphically highest site that will be discussed here. Stonehenge, Gully, and DISC crop out in ascending order and TVOR S and TVOR are probably stratigraphically lower than Stonehenge, although lack of outcrops makes this uncertain. All are from the Miocene upper Fleming Formation, Castor Creek Member, Barstovian Land Mammal Age (Schiebout 1994, 1996, 1997a; Schiebout et al. 1996). Three of the Fort Polk conglomerate sites are located in bulldozed, man-made sites and the remaining four in creek beds or in erosional gullies. The largest man-made exposure, DISC Site, covers a 7.5 acre bulldozed area. The main conglomerate layer exposed at DISC is almost flat lying and underlies at least two acres. It is usually covered with a clay and nodule erosional veneer (Figure 19 and Figure 20), and is seen clearly only in freshly dug surfaces or areas where erosional gullies cut the layer. In some areas of the site, there are two distinct layers of the extensive conglomerate separated by an approximately 2 $\mathrm{cm}$ thick clay layer, and in others, there is a single conglomerate layer (Figure 21). The deposit's topology may well have been that of a perforated sheet. The upper layer, where two conglomerate layers are present, is finer grained and richer in sand, with fewer nodules. Cross bedding can be seen in some places. Isolated small lenses of conglomerate are also exposed at DISC (igure 22).

Conglomerate in natural exposures like TVOR Site (Figure 23 and Figure 24) is usually a near horizontal, tabular ledge, between $10-25 \mathrm{~cm}$ thick, and about 1 to $1.5 \mathrm{~m}$ wide, often showing some evidence of trough cross-bedding. It is usually overlain and underlain by a massive gray clay of variable thickness, often with common $\mathrm{CaCO}_{3}$ nodules. Jones et al. (1995) provided a detailed description of rocks and of cores drilled in the Fort Polk Miocene fluvial deposits for the purpose of understanding the processes of deposition that yielded the fossils. For more detailed description of thin section petrography than given below, see Jones et al. (1995) and Schiebout (1997b), and for more detailed site descriptions see Schiebout (1997b). Terminology of the following discussion is after Folk (1959).

Conglomerates at Fort Polk are composed primarily of well-rounded, carbonate peloids, which appear similar to the carbonate nodules found in the paleosols of the cores (Jones et al. 1995). The lower level of the main productive conglomerate at DISC is a pelsparite composed of carbonate peloids $(51 \%)$ and other sedimentary rock fragments (22\%), which are cemented with carbonate cement (Figure 25). Some of the carbonate peloids show septarian structure formed by relatively slower desiccation and crystallization of their center. The stratigraphically higher layer of the main conglomerate (Figure 26) is a carbonate arenite made up of carbonate peloids, quartz grains, feldspar grains, volcanic rock fragments, and other sedimentary rock fragments and containing less cement. The conglomerate bed from an even more fossil-productive Fort Polk site, TVOR Site, (Figure 27) is a pelsparite composed mainly of carbonate peloids (41\%) cemented by either carbonate cement $(11 \%)$ or a black mineral cement $(18 \%)$, which formed before the carbonate cement, probably including iron and manganese oxides. 


\section{Miocene, East Texas}

A single boulder of pedogenic-nodule-rich conglomerate (Figure 28) from the Fleming Formation, found at a classic east Texas Miocene site known for yielding mammals of the Cold Spring Local Fauna, is yielding microvertebrates after acid dissolution and screening (Schiebout and Ting in press). This work extends the dissolving of conglomerates from the Fleming Formation westward into Texas and offers the possibility of biostratigraphic correlation of faunas of small vertebrates of the Fort Polk region with a sequence of Miocene faunas developed primarily on large vertebrates (Wilson 1956; Patton 1971; Prothero and Manning 1987).

\section{Recognizing the Rocks in the Field}

Surface nodules are certainly a good clue, but not all areas in which nodule-rich paleosols have eroded to litter the surface will have lenses of ancient pedogenic nodule concentrates. The presence of light-colored calcium carbonate nodules in rocks also rich in iron oxides and/or manganese gives a fairly distinctive surface texture (Figure 23 and Figure 29). In all three areas under study the rocks in question are among the most erosion resistant of the deposits and at the Cretaceous and Miocene sites, they are by far the most resistant and are recognizable in small outcrops as seen in Figures 22, 23, 29, and Figure 30.

\section{TAPHONOMY}

\section{Formation of the Conglomerates}

Fossiliferous, nodule-rich conglomerates form in areas where pedogenic nodules and vertebrate remains are a substantial part of the coarse fraction of sediments available; i.e., they are likely to be prominent in fine-grained systems in regions where calcareous soils tend to form, and where rates of deposition are comparatively slow, allowing good development of soils. Kraus (1997) reported better developed paleosols in Eocene alluvial beds of the Willwood Formation in Wyoming in areas estimated to have had a 0.3 and $0.4 \mathrm{~mm} / \mathrm{yr}$ rate of rock accumulation than for areas in which the rate of accumulation was estimated between 0.6 and $0.7 \mathrm{~mm} / \mathrm{yr}$. Kraus and Bown (1993) estimated the Willwood rates of accumulation. In the late Paleocene, the Big Bend area received much slower deposition and is less fossiliferous than late Paleocene sites farther north like those of Wyoming, some of which received over 25 times more sediment per million years (Sloan 1987; Schiebout 1995). It is possible that the breaking of bones and teeth, fragments of which are common in the screening residues, has been facilitated by the nodule development itself. Porous bone tends to become heavily encrusted and/or broken where nodules are forming (Figure 31). This has resulted in a generally poor paleontological record for areas of slow deposition and nodule-rich soils, in part because of damage to the fossils and in part because of problems involved in getting the nodular material off of the fossils.

Concentration of nodules and bones can result from reworking during channel 
meandering, overbank fluvial erosion due to flooding, avulsion, or erosion resulting from a drop in base level that causes rivers to entrench, overbank addition to interfluvial areas to slow or stop, and erosion to begin to denude the interfluves. The conglomerates of very limited lateral extent, like Joe's Bonebed conglomerate from the Paleocene deposits of Big Bend or small lenses exposed at the DISC Site at Fort Polk (Figure 22), probably represent material washed into small channels or low areas on the floodplain. The Cretaceous Aguja conglomerates are examples of lag deposits in larger channels. Wells (1983) discussed pedogenic nodule lag deposits that included some fish and mammal material, from the bases of small channels in sand-poor redbeds from the Eocene deposits of northern Pakistan, and that he interpreted as formed by shortlived, briefly active streams, in an environment analogous to parts of modern southern and central Australia.

The most laterally extensive deposit at DISC site in the Louisiana Miocene represents a locally variable blanket of material concentrated from soils by erosion. The thin mudstone layer between upper and lower portions of the main conglomerate may represent an avulsion or crevasse splay event flooding part of the area or may represent local sheet wash. The extreme fragility of some of the fossils recovered from the DISC site precludes long transport, but the well-rounded condition of many bone pieces (particularly those from larger animals), suggests some transport for them, perhaps including several cycles of reworking. A larger scale example of similar processes has been reported from the Lower Jurassic of South Africa, where regional degradation resulting from a base level drop produced a pedogenic nodule concentrate $0.5-1.25 \mathrm{~m}$ thick covering more than 11,000 square $\mathrm{km}$, rich in vertebrate remains from a large synapsid (mammal-like reptile), and having the topology of a perforated sheet (Smith and Kitching 1997). DISC has also yielded remains of large vertebrates (horses and the early camel relative Prosynthetoceras, (Figure 32). They were found at or slightly above its upper surface and probably represent animals buried when deposition of overbank fine sediment resumed in the area. Behrensmeyer (1982) discussed paleosol assemblages representing 4,000-9,000 year durations in her discussion of time interval sampling in a terrestrial environment, and Smith and Kitching (1997) estimated 50,000 years for the accumulation of the widespread condensed bed they studied in the Jurassic of South Africa. The accumulation of the DISC main conglomerate probably took more time than the development of regular paleosol fossil assemblages, because it includes a period of denudation and concentration in addition to paleosol formation, and probably less time than the thicker and more extensive South African deposit.

Bown and Kraus (1981) discussed vertebrate concentrations in mudstones from lower Eocene floodplain sediments of Wyoming, concluding that the bones accumulated as lags in the A horizons of paleosols with little effect of sorting in water. They reported that small mammal teeth make up $70 \%$ of the teeth recovered, teeth that would readily travel with sand-sized particles, and used their presence, the lack of sand, and other evidence to conclude that hydraulic sorting was not significant in these deposits (Bown and Kraus 1981 p. 48-49). All of the Fort Polk conglomerates include nodules and bones rounded in water transport (Figure 25-27, and Figure 33), some show distinctive cross-bedding 
(Figure 24), and some of the most fossiliferous include considerable sand (Figure 27). Many of the fossil remains from the pedogenic nodule conglomerates moved as sedimentary particles when carried by water, as did vertebrate remains discussed by Voorhies (1969), Dodson (1973), and Korth (1979). Those that accumulated in channel lags, for example, the deposit at TVOR Site, Fort Polk, were certainly subjected to such processes. Small mammal teeth (Figure 34) are moderately transportable in water compared to other skeletal elements. They belong to Korth's (1979) dispersal category II or III, with I having the lowest settling rate (ribs), and IV the highest, for example, mandibles. High percentages of fish teeth (including pharyngeal teeth) are found with the terrestrial mammal teeth at Fort Polk (Table 1, Figure 35). When identifiable, they have proved to be from fresh-water fish, that had to be either transported into the areas where nodules and terrestrial vertebrate teeth were accumulating, or the nodules and mammal teeth had to be transported to join them. These factors indicate that the Fort Polk conglomerates include more reworking and transport in water and mixing of materials, and comparatively more time averaging than the fossil accumulations described by Bown and Kraus (1981). The lower part of DISC main conglomerate is more similar to deposits such as those described by Bown and Kraus (1981) than are TVOR or Stonehenge sites, where more transport occurred, at Fort Polk. It shows a lower concentration of all kinds of teeth, fewer fish teeth per unit of weight when compared to mammals, and more large bone fragments versus small bone fragments, than they do (Figure 35, Table 1). A rough correspondence between degree of cementation with calcium carbonate and productivity of teeth, including terrestrial mammal teeth, is seen at Fort Polk sites. Conglomerates like TVOR where more winnowing has taken place have better cementation (Figure 27) and more fossils, including a higher percentage of fish teeth (Table 1). Clayey conglomerates like DISC (Movie 1, Figure 21) have fewer fossils because they represent both less erosion and concentration of the harvest of small teeth from soils, and less transport which added remains such as those of fresh-water fish.

Fort Polk conglomerate sites offer the possibility of studying a progression of sites through time in the Louisiana Miocene. Their fossil faunas are being examined for trends. Lindsay (1972) reported a size increase upsection in the rodent Copemys in the California Barstovian, and initial results examining four sites (from lowest to highest: TVOR, Stonehenge, Gully, and DISC Sites), also suggested a size increase in this animal through time. Further screening and analysis, however, produced a very different picture (Figure 36), emphasizing the value of continuing processing to extract more than the handful of small forms initially available.

The unique situation and method of recovery of fossils at Fort Polk guarantees results as long as the conglomerates can be located and processed. The faunal list, currently including 26 land mammals belonging to nine orders, may eventually include 100 mammals, like the Myers Farm Site in Nebraska (Corner 1976). Although more than 3,000 specimens are catalogued, screening continues because it is especially important to increase samples of new species and rare forms. Hedgehogs (Schiebout 1996) and a new species of tiny beaver are represented by less than ten teeth apiece. In a Miocene 
possibly warmer than the modern western Louisiana climate, frugivorous bats might have survived, but none have been found as yet.

The close association of vertebrate faunas and pedogenic nodules in the conglomerates offers an opportunity for fruitful geochemical research. Geochemical studies of delta ${ }^{13} \mathrm{C}$ and delta ${ }^{18} \mathrm{O}$ compositions of pedogenic carbonates from the Fort Polk Miocene paleosols and nodule-rich conglomerates are underway by Paul Aharon (personal commun., 1997; Schiebout 1997b). Pedogenic nodule delta ${ }^{13} \mathrm{C}$ compositions reflect original soil $\mathrm{CO}_{2}$ which, in turn, reflects the nature of the original biomass, and delta ${ }^{18} \mathrm{O}$ is known to have a very strong positive correlation with the isotope composition of local rainfall (Cerling 1984).

\section{CONCLUSIONS}

Pedogenic nodule conglomerates, no matter how unprepossessing, are potential vertebrate fossil sites. The nodule horizons also offer a fossil concentration method that may be stratigraphically repeated to offer a periodic sampling. They are recognizable in very small outcrops and are thereby recognizable even in heavily vegetated areas such as eastern Texas and western Louisiana. Although extraction of large faunas from them is a large-scale, slow endeavor, use of these rocks makes vertebrate paleontology somewhat convergent upon micropaleontology, where most selected rock samples will be productive if properly prepared. Vertebrate paleontology in general depends on a high degree of luck for preservation and discovery to yield specimens, whereas these conglomerates offer a fossil concentration method that works with a high degree of certainty, and their resistance to erosion makes locating them relatively easy. Areas of particular promise for fossils from pedogenic nodule conglomerates include: finding small vertebrates at sites where none were known, finding rare vertebrates where outcrops are minuscule, stratigraphic repetition of good sites, and finding vertebrates closely associated with pedogenic nodules on which geochemical work can provide data on ancient soils and vegetation.

\section{ACKNOWLEDGMENTS}

Support for research in Big Bend National Park was provided by the National Science Foundation, the Dinosaur Society, the LSU Geoscience Associates, the LSU Museum of Natural Science, the LSU Department of Geology and Geophysics, and Joe Schiebout. Many Museum of Natural Science volunteers have helped with the current research on Big Bend. They include Jean Sankey, Jason Ramcharan, Margaret Smith, Charlsa Moore, Tina Aherns, and Sara Wachter. Research in Big Bend National Park was conducted under Antiquities Act Permits granted to the LSU Museum of Geoscience and the LSU Museum of Natural Science. Cooperation of U. S. National Park Service employees is much appreciated. I wish to thank Frances and Earl Hodges, landowners near Cold Spring, Texas, for their cooperation in research in that area. 
Help from individuals at Fort Polk, especially Director of Public Works, Rory A. Salimbene, LTC, EN and his environmental staff, including Dr. Charles Stagg, James Grafton, and Robert Hays, made the western Louisiana research possible. Paleontological research on Fort Polk is currently supported by U. S. Army FORSCOM, on contracts to the LSU Museum of Natural Science, administered by Dr. Frank Servello, Fort Worth District, U. S. Army Corps of Engineers, issued to Prewitt and Associates, Inc. Mapping in the vicinity has also been supported by the United States Geological Survey via the EDMAP program. Support has also been provided by the LSU Museum of Natural Science. Pam Borne and Megan Jones helped with Cold Spring field work and they and Alton ("Butch") Dooley, Jr., Brett Dooley, and many other LSU students and faculty assisted in field work on Fort Polk. Julitta Kirkova did thin section point counts. The LSU Museum of Natural Science vertebrate paleontological bulk acid lab is located in the LSU Basin Research Institute Well Core and Sample Library, and their cooperation is appreciated.

Timothy Patterson from Carleton University in Ottawa, Canada, two anonymous reviewers, Louis Jacobs from Southern Methodist University in Texas and Ruth Hubert, Arnold Bouma, Paul Aharon, and Paul Heinrich from LSU provided helpful comments on this manuscript. Photographs are by Judith Schiebout unless otherwise noted. The following staff of the LSU Center for Instructional Technology provided assistance: Christie Cazes digitized and improved images for the figures and table, Tom Davis shot videotape, Dan Brock edited and digitized it, and Marti Ratcliff and Dan Brock did the final editing.

\section{REFERENCES}

Behrensmeyer, A. K. 1982. Time resolution in fluvial vertebrate assemblages. Paleobiology, 8:211-227.

Bown, T. M. and Kraus, M. J. 1981. Vertebrate fossil-bearing paleosol units (Willwood Formation, Lower Eocene, Northwest Wyoming, U.S.A.): Implications for taphonomy, biostratigraphy, and assemblage analysis. Palaeogeography, Palaeoclimatology, Palaeoecology, 34:31-56.

Cerling, T. E. 1984. The stable isotope composition of modern soil carbonate and its relation to climate. Earth and Planetary Science Letters, 71:229-240.

Corner, R. G. 1976. Early Valentinian vertebrate local fauna from southern Webster County, Nebraska. Unpublished Ms. Thesis, University of Nebraska at Lincoln, Lincoln, Nebraska, USA.

Dodson, P. 1973. The significance of small bones in paleoecological interpretation. University of Wyoming Contributions in Geology, 12: 15-19.

Dooley, A. C. Jr., Schiebout, J. A. and Dooley, B. S. In press. An inexpensive, environmentally friendly method for bulk acid processing of carbonate rocks to obtain microvertebrates. In Leiggi, P. and P. May (eds.), Vertebrate Paleontological Techniques, v. 2, Cambridge University Press, New York, NY.

Folk, R. L. 1959. Practical petrographic classification of limestones. American Association of Petroleum Geologists Bulletin, 43:1-38. 
Folk, R. L. 1968. Petrology of Sedimentary Rocks. Hemphill's, Austin, Texas.

Hibbard, C. W. 1949. Techniques of collecting microvertebrate fossils. Contributions Museum Paleontology, University of Michigan, 3: 7-19.

Jones, M. H., Schiebout, J. A. and Kirkova, J. T. 1995. Cores from the Miocene Castor Creek Member of the Fleming Formation, Fort Polk, Louisiana: Relationship to the Outcropping Miocene terrestrial vertebrate fossil-bearing beds. Gulf Coast Association of Geological Societies Transactions, 45: 293301.

Korth, W. W. 1979. Taphonomy of microvertebrate fossil assemblages. Annals Carnegie Museum, 48: 235-285.

Kraus, M. J. and Bown,T. M. 1993. Short-term sediment accumulation rates derived from Eocene alluvial paleosols. Geology, 21:743-746.

Kraus, M. J. 1997. Lower Eocene alluvial paleosols: pedogenic development, stratigraphic relationships and paleosol/landscape associations. Palaeogeography, Palaeoclimatology, Palaeoecology, 129: 387-406.

Lehman, T. M. 1985. Stratigraphy, sedimentology, and paleontology of upper Cretaceous (Campanian-Maastrichtian) sedimentary rocks in Trans-Pecos Texas. Unpublished Ph.D. Dissertation, University of Texas, Austin, USA.

Lindsay, E. H. 1972. Small mammal fossils from the Barstow Formation, California. University of California Publications in Geological Sciences, 93:1-104.

Patton, T. H. and Taylor, B. E. 1971. The Synthetoceratinae (Mammalia, Tylopoda, Protoceratidae). Bulletin of the American Museum of Natural History, 145:119-218.

Prothero, D. R., and Manning, E. M. 1987. Miocene rhinoceroses from the Texas Gulf Coastal Plain. Journal of Paleontology, 61:388-423.

Rutsky, I. S., Elvers, W. B., Maisey, J. G. and Kellner, A. W. A. 1994. Chemical preparation techniques, p. 155-186. In Leiggi, P. and P. May (eds.), Vertebrate Paleontological Techniques, v. 1, Cambridge University Press, New York, NY.

Sankey, J. T. 1995. A Late Cretaceous small vertebrate fauna from the upper Aguja Formation, Big Bend National Park, Texas. Geological Society of America, Abstracts with Programs 27:A-387.

Sankey, J. T. 1996. Late Cretaceous small vertebrates from calcarous conglomerates, upper Aguja Formation, Big Bend National Park, Texas--An untapped resource. Journal of Vertebrate Paleontology, Abstracts of Papers, 16: 63A.

Sankey, J. T. 1997. Late Cretaceous vertebrate paleontology and paleoecology, upper Aguja Formation, Big Bend National Park, Texas. Journal of Vertebrate Paleontology, Abstracts of Papers.

Sankey, J. T. and Schiebout, J. A. 1997. Late Cretaceous vertebrate paleontology and magnetostratigraphy, upper Aguja Formation, Big Bend National Park, Texas. Geological Society of America, Abstracts with Programs, 29.

Sankey, J. T. 1998. Vertebrate paleontology and magnetostratigraphy of the Upper Aguja Formation (Late Campanian), Talley Mountain area, Big Bend National Park, Texas. Unpublished Ph.D. dissertation, Louisiana State University, Baton Rouge, Louisiana, USA.

Schiebout, J. A. 1974. Vertebrate paleontology and paleoecology of Paleocene Black Peaks Formation, 
Big Bend National Park, Texas. Texas Memorial Museum Bulletin, 24:1-87.

Schiebout, J. A. 1979. Paleoecology of the Paleocene Black Peaks Formation, Big Bend National Park, Texas. Proceedings of the First Conference on Scientific Research in the National Parks. National Park Service Transactions and Proceedings, 5:737-742.

Schiebout, J. A. 1981. The stratigraphic and paleogeographic importance of Paleocene and early Eocene deposits in Big Bend National Park. Proceedings of the Second Conference on Scientific Research in the National Parks, National Park Service Transactions and Proceedings, 5:332-347.

Schiebout, J. A., Rigsby, C. A., Rapp, C. D., Hartnell, J. A. and Standhardt, B. R. 1987. Stratigraphy of Late Cretaceous, Paleocene, and early Eocene rocks of Big Bend National Park, Texas. Journal of Geology, 95:359-375.

Schiebout, J. A. 1994. Fossil vertebrates from the Castor Creek Member, Fleming Formation, western Louisiana. Gulf Coast Association of Geological Societies Transactions, 44: 675-680.

Schiebout, J. A. 1995. The Paleocene/Eocene transition on Tornillo Flat in Big Bend National Park, Texas. In V. L. Santucci and L. McClelland (eds.), National Park Service Paleontological Research, National Park Service Technical Report NPS/NRPO/ NRTR-95/16: 40-45.

Schiebout, J. A. 1996. A Miocene hedgehog (Mammalia: Erinaceidae) from Fort Polk in western Louisiana. Occasional Papers LSU Museum Natural Science, 70: 1-9.

Schiebout, J. A., Jones, M. H., Wrenn, J. H. and Aharon, P. R. 1996. Age of the Fort Polk Miocene terrestrial vertebrate fossil sites. Gulf Coast Association of Geological Societies Transactions, 46:373-378.

Schiebout, J. A. 1997a. The Fort Polk Miocene microvertebrate sites compared to those from east Texas. The Texas Journal of Science, 49:23-32.

Schiebout, J. A. 1997b. Paleofaunal survey, collecting, processing, and documentation at two locations on Fort Polk, Louisiana. Louisana State University Report to the Corps of Engineers, Fort Worth District, Texas, USA.

Schiebout, J. A. and S. Ting. in press. Miocene terrestrial microvertebrates recovered from conglomerate rich in pedogenic nodules, Fleming Formation near Coldspring, Texas. Texas Journal of Science, v. 50(3).

Judith A. Schiebout, Julia T. Sankey, Barbara R. Standhardt, and Jason Ramcharan. in press. Louisiana State University Museum of Natural Science Collections from Late Cretaceous through Early Eocene Microvertebrate Sites, Big Bend National Park, Texas. National Park Service Paleontological Research, National Park Service Technical Reports.

Sloan, R. E. 1987. Paleocene and latest Cretaceous mammal ages, biozones, magnetozones, rates of sedimentation, and evolution. Geological Society of America Special Paper, 1:209.

Smith, R. and Kitching, J. 1997. Sedimentology and vertebrate taphonomy of the Tritylodon Acme Zone; a reworked palaeosol in the Lower Jurassic Elliot Formation, Karoo Supergroup, South Africa.

Palaeogeography, Palaeoclimatology, Palaeoecology, 131:29-50.

Voorhies, M. R. 1969. Taphonomy and population dynamics of an early Pliocene vertebrate fauna, Knox County, Nebraska. University of Wyoming Contributions in Geology Special Papers, 1: 1-69.

Wells, N. A. 1983. Transient streams in sand-poor redbeds: early-Middle Eocene Kuldana Formation of northern Pakistan. Special Publications International Association Sedimentologists, 6:393-403. 
Wilson, J. A. 1956. Miocene formations and vertebrate biostratigraphic units, Texas Coastal Plain. American Association of Petroleum Geologists Bulletin, 40:2233-2246. 
Figure 1. Shrew upper molar from TVOR Site, Miocene of Fort Polk, Louisiana. Occlusal view. Scanning electron micrograph by Xiaogang Xie and Suyin Ting.

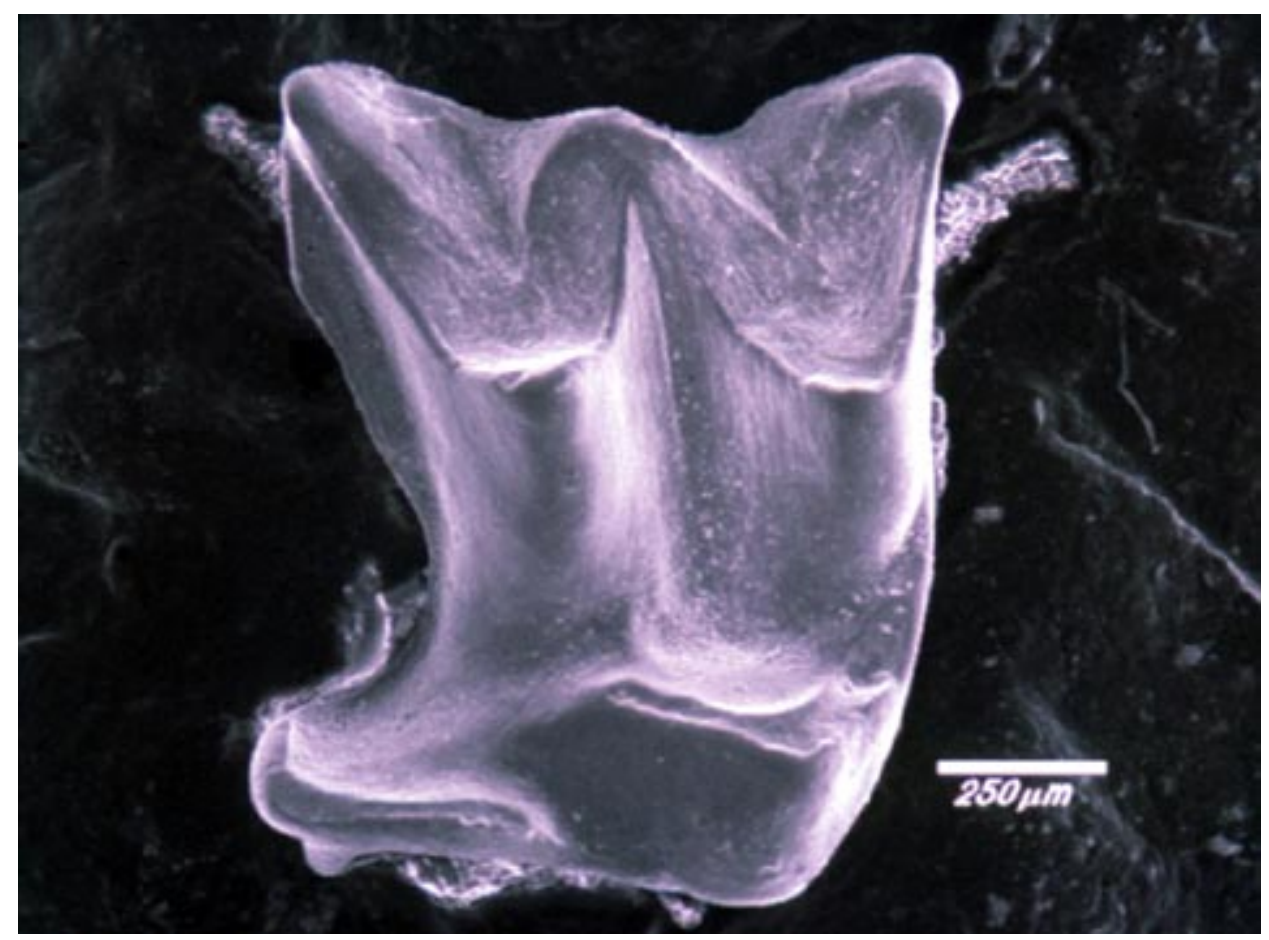


Figure 2. Location map showing Fort Polk in Louisiana, and Big Bend National Park and Coldspring in Texas. Permits are required for research on Fort Polk and in Big Bend National Park.

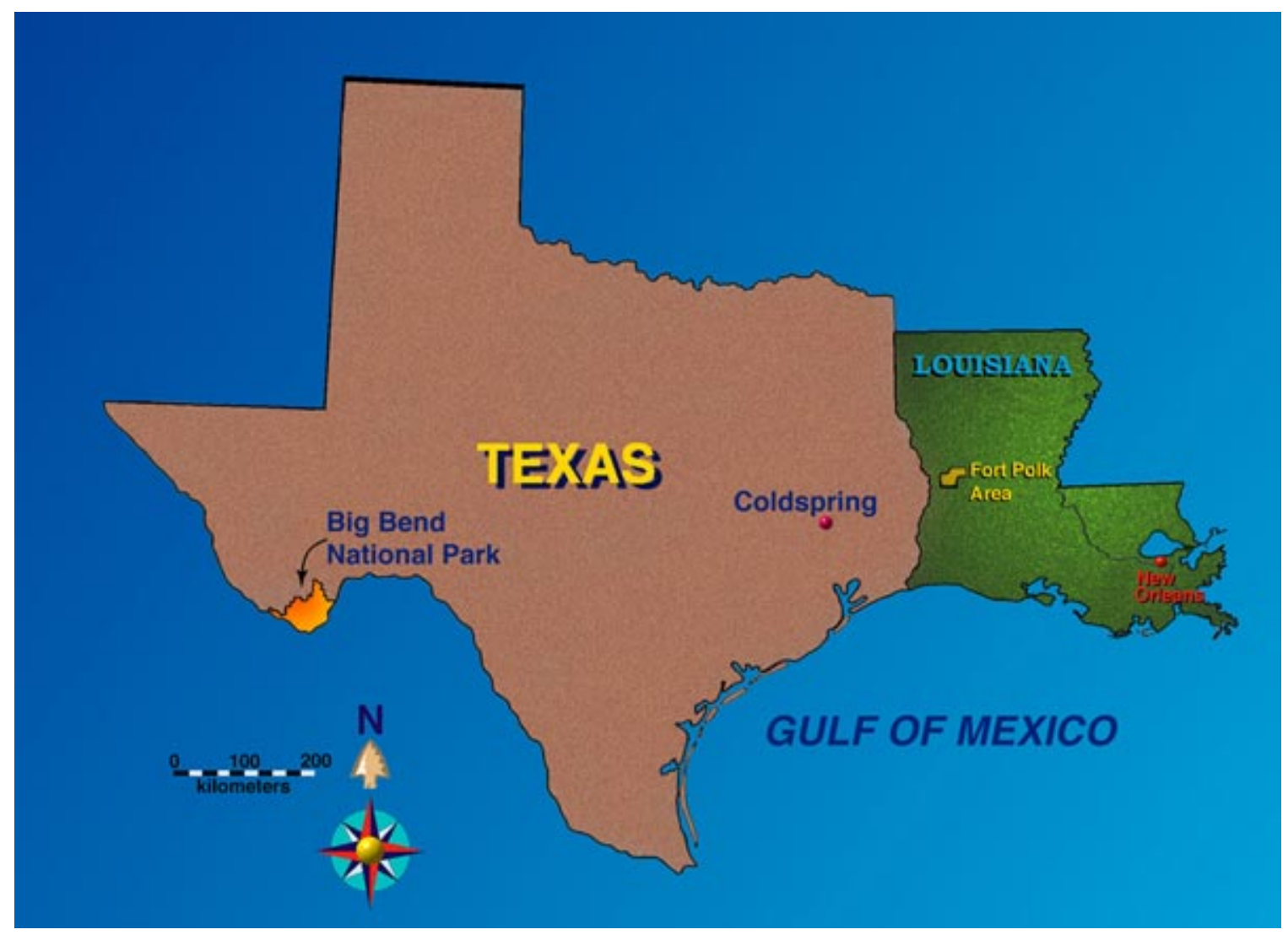


Figure 3. Lateral view of merychippine horse mandible encased in pedogenic nodular material from DISC Site, Miocene of Fort Polk, Louisiana. Photograph by Kerry Lyle.

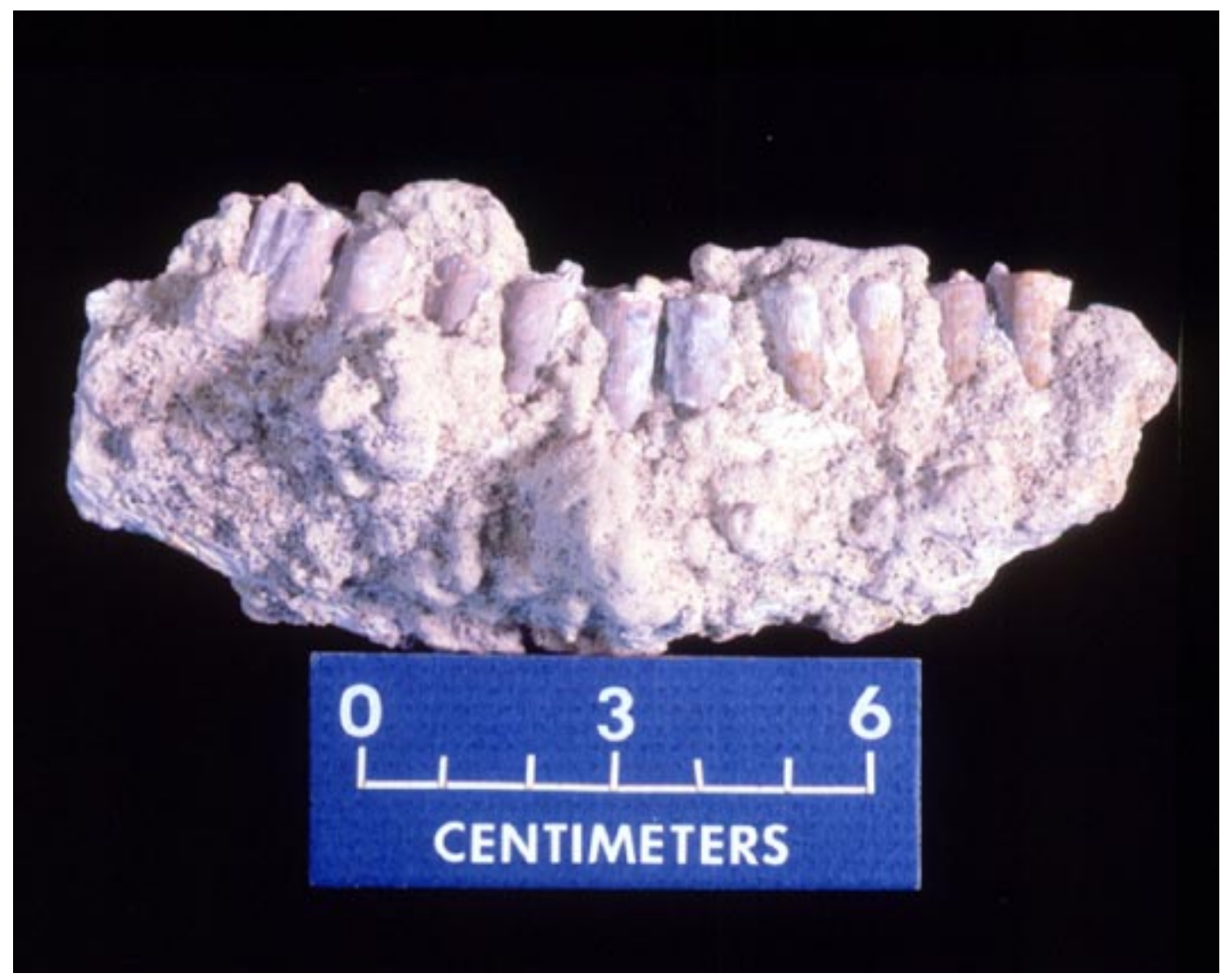


Figure 4. Joe's Bonebed, Paleocene Black Peaks Formation, Big Bend National Park, Texas. Fluvial mudstone slopes are heavily covered with pedogenic nodules. Remains of large and medium-sized vertebrates were recovered from float all along the slope pictured here. A small lens of nodule conglomerate from this slope yielded the microvertebrate fauna from Joe's. Suyin Ting (L), Joe Schiebout (M), and Jill Hartnell (R).

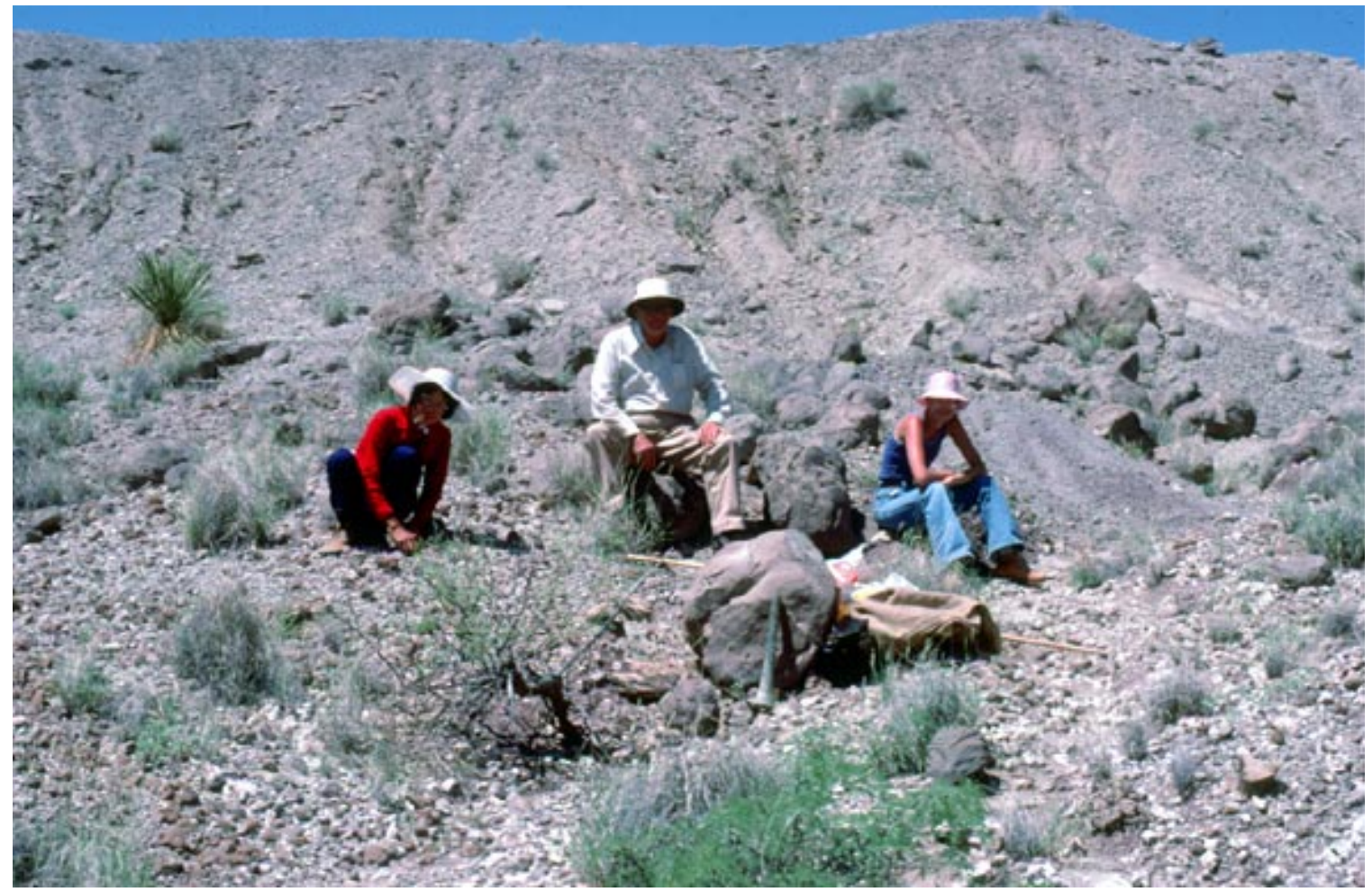


Figure 5. Judy's conglomerate, Late Cretaceous, Aguja Formation, Big Bend National Park, Texas, with Julia Sankey. Photograph by Jean Sankey.

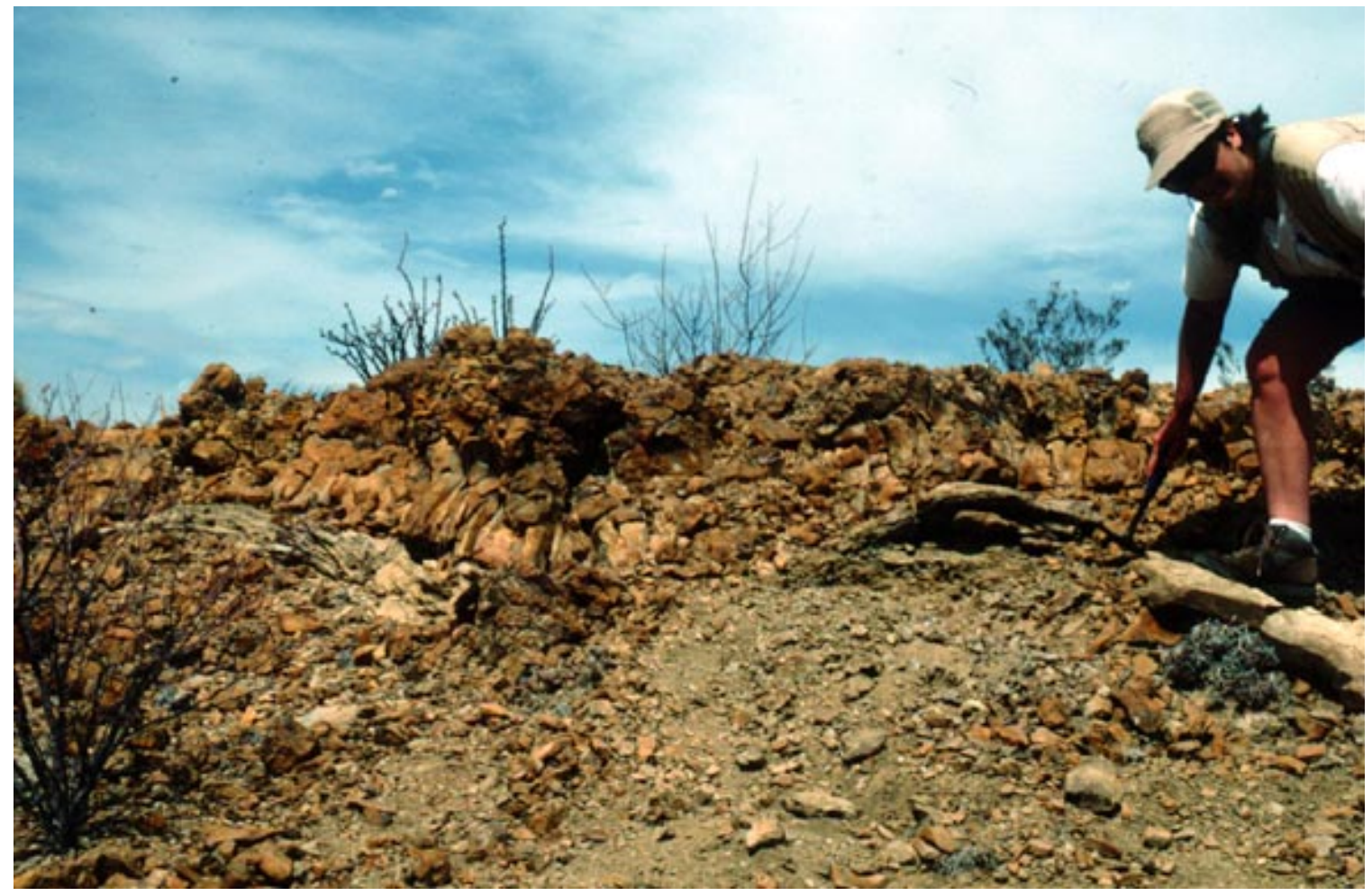


Figure 6. LSU field crew wet screening untreated mudstone in the Rio Grande, Big Bend National Park, Texas.

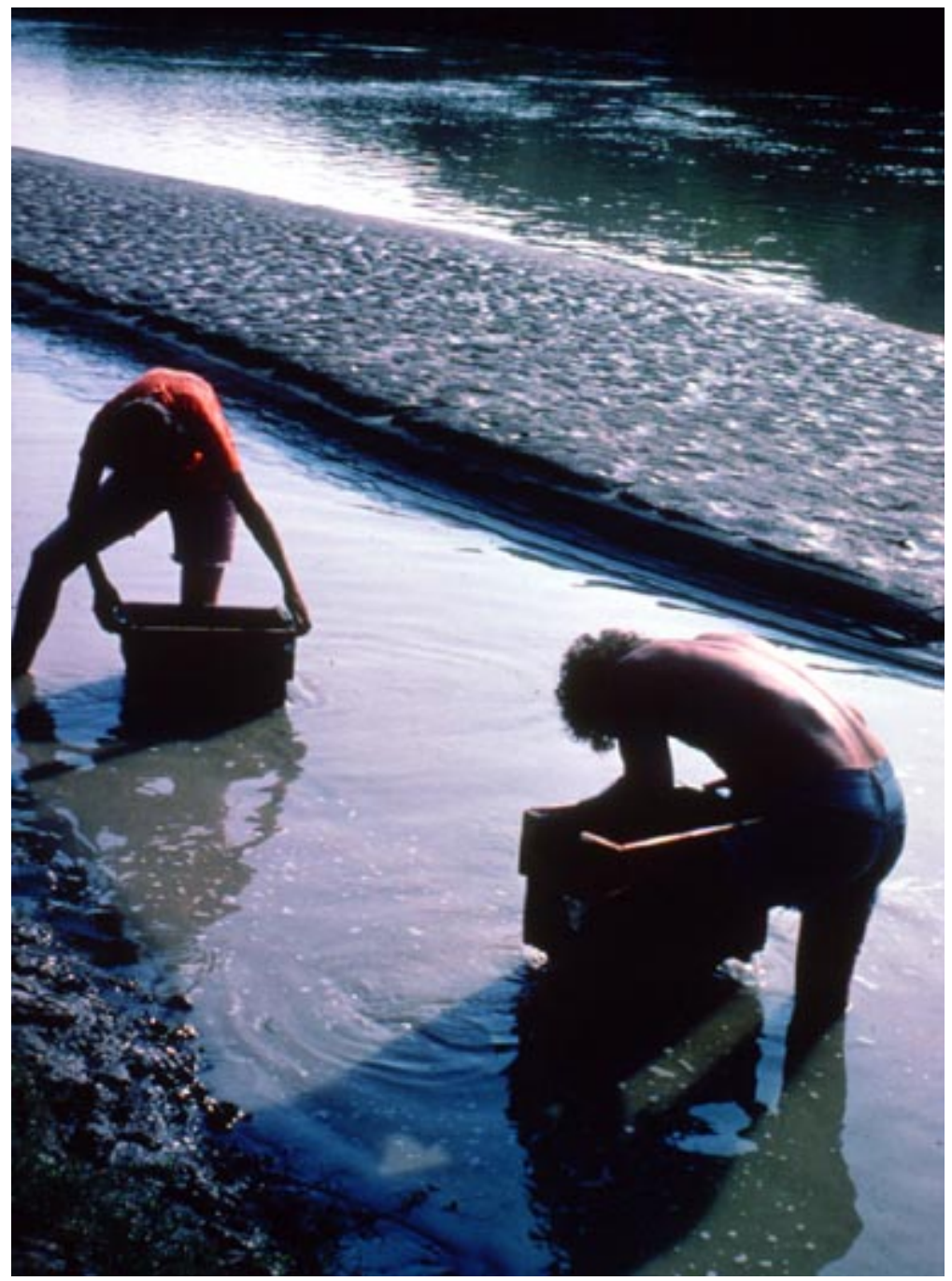


Figure 7. Robert Rainey $(L)$ and Judith Schiebout $(R)$ bag conglomerate at Joe's Bonebed, Big Bend National Park, in 1970. Photograph by John A. Wilson.

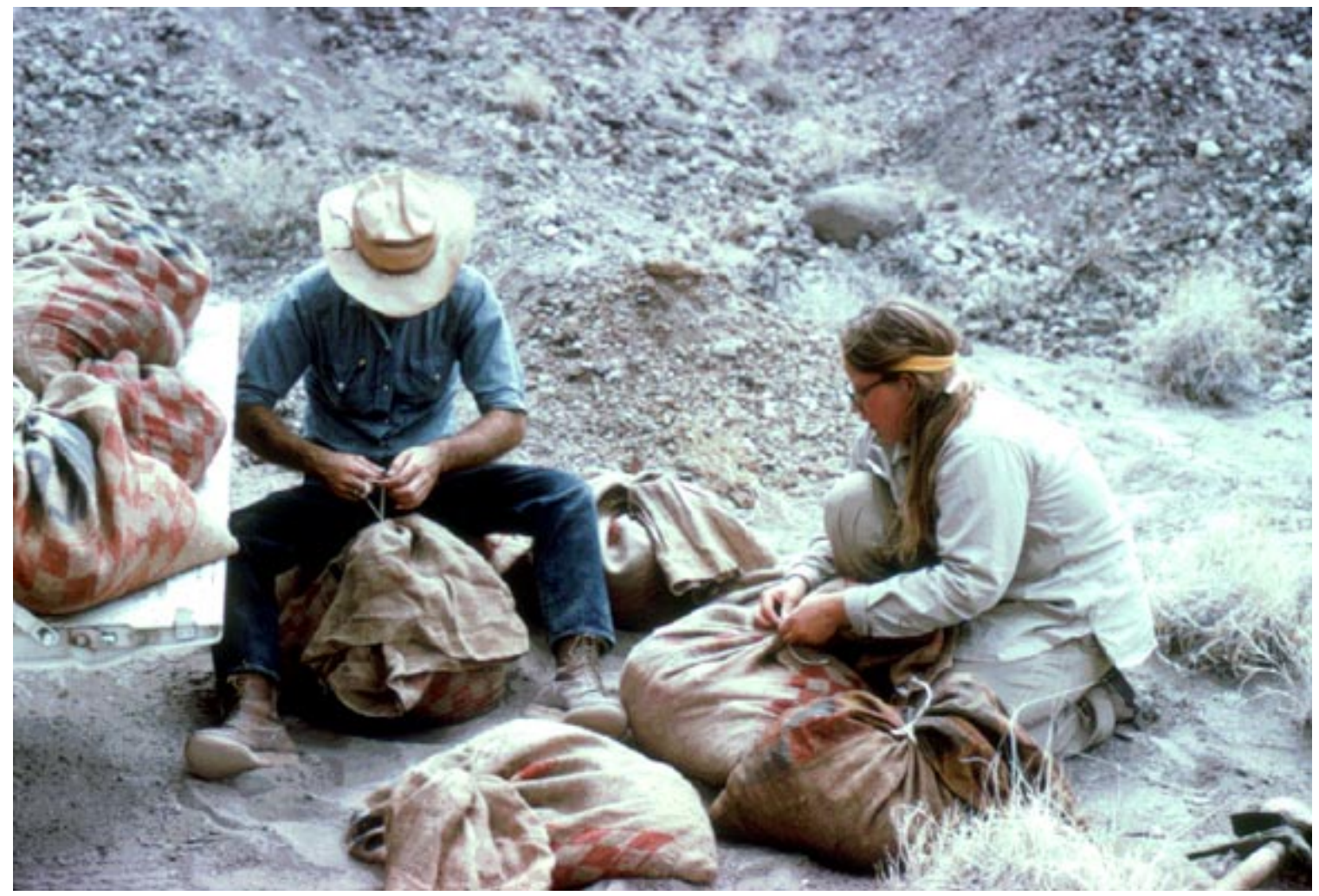


Figure 8. Helicopter carries bags for screening from remote sites in Big Bend National Park, Texas in 1984.

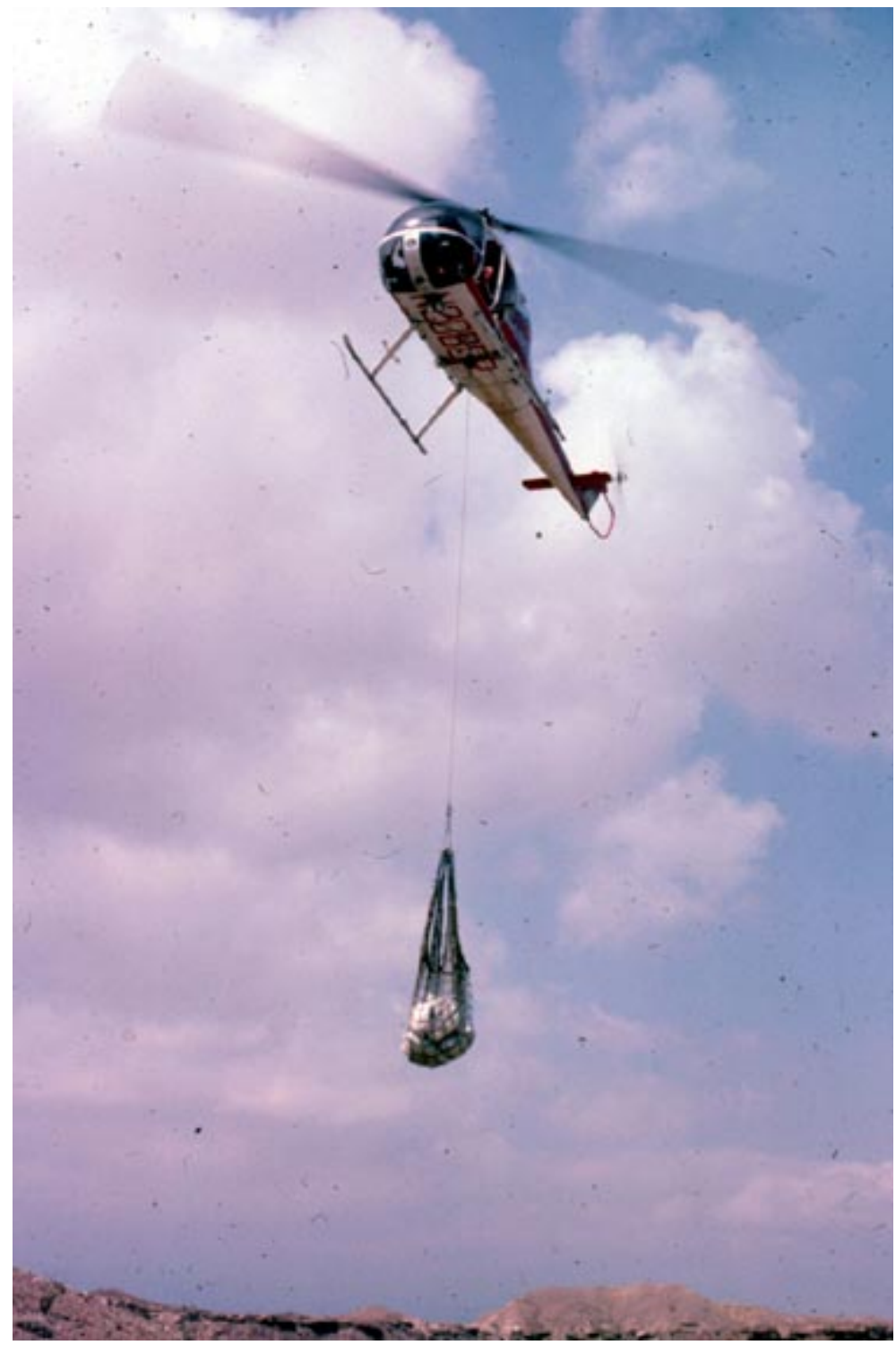


Figure 9. Bags of rock from the Louisiana Miocene as brought in from the field, closed with duct tape. Airless jackhammer and conglomerate piece from Stonehenge Site rest on the bags.

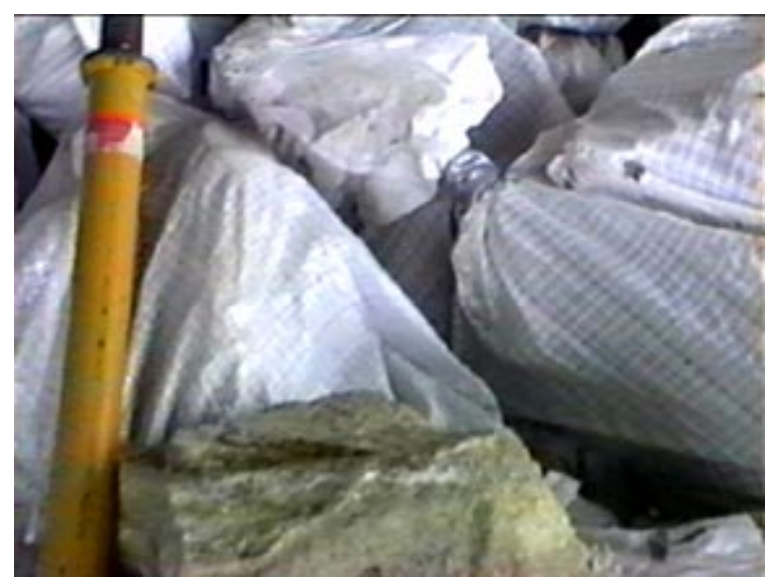


Figure 10. Slabs of conglomerate from Stonehenge Site, Miocene of Fort Polk, which have been removed by heavy equipment from a gully where they were exposed. Later, they were broken up by gasoline-powered jackhammer for bagging. Robert Hays (L) and Suyin Ting (R). Photograph by Pam Borne.

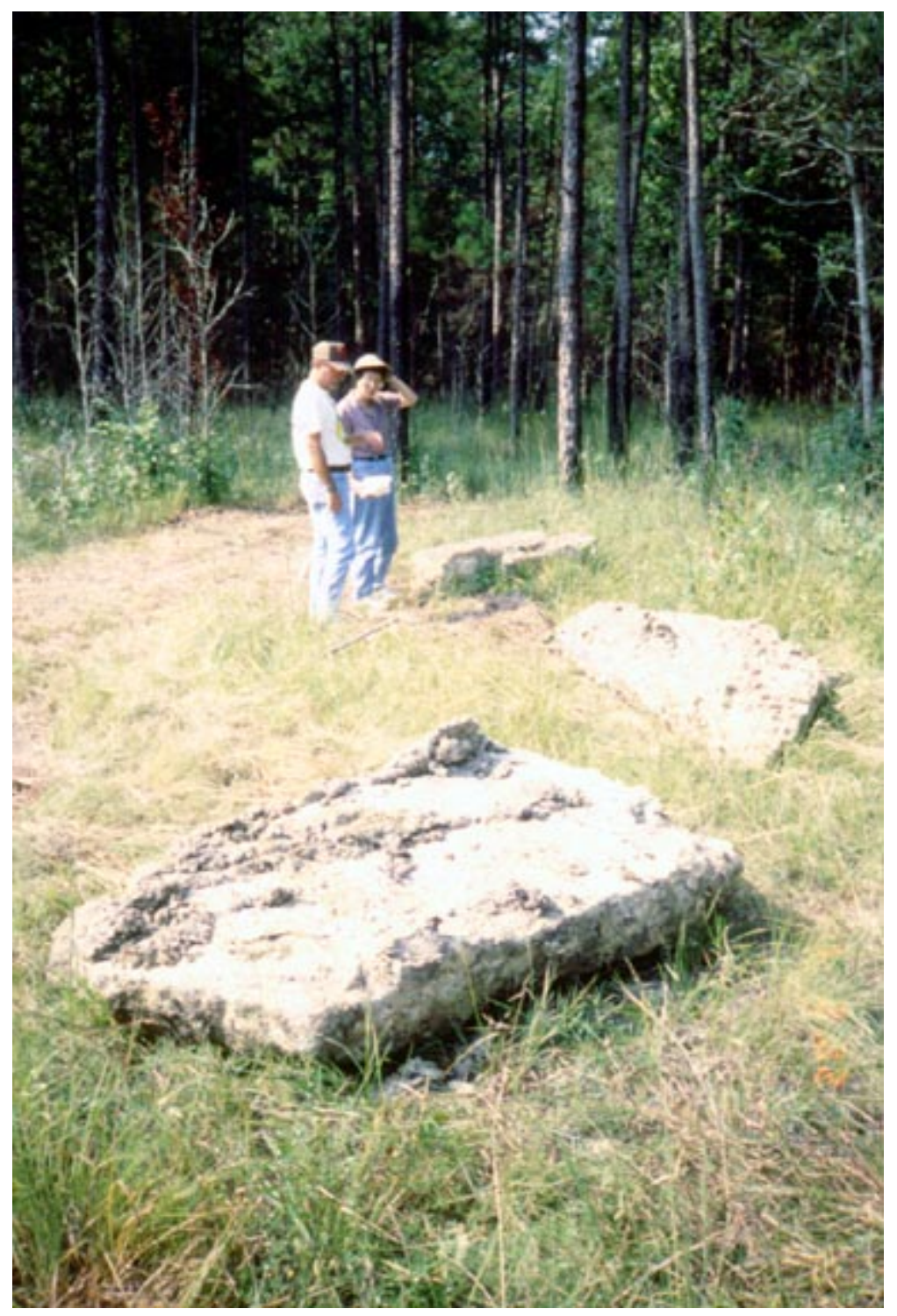


Figure 11. Dumping a screen on a drying tray.

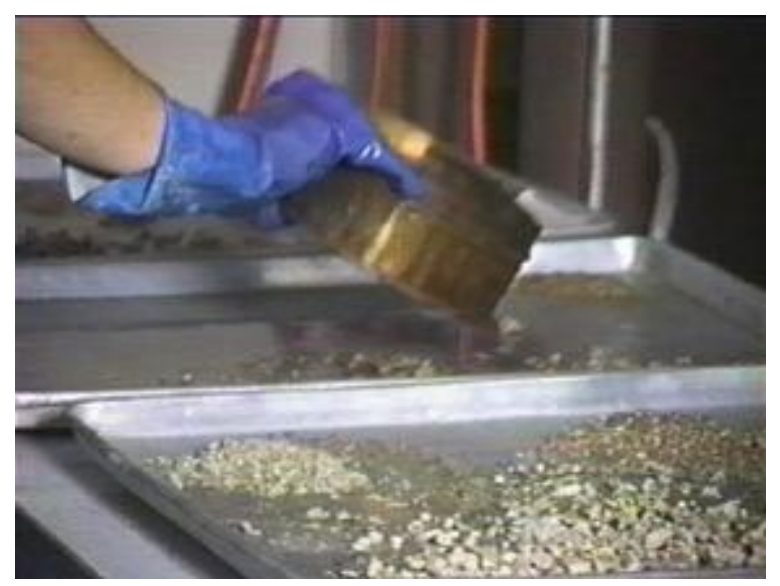


Figure 12. Dried screening residue from Stonehenge Site showing nodules darkened with iron and manganese oxides. Dr. Schiebout indicates a bone fragment.

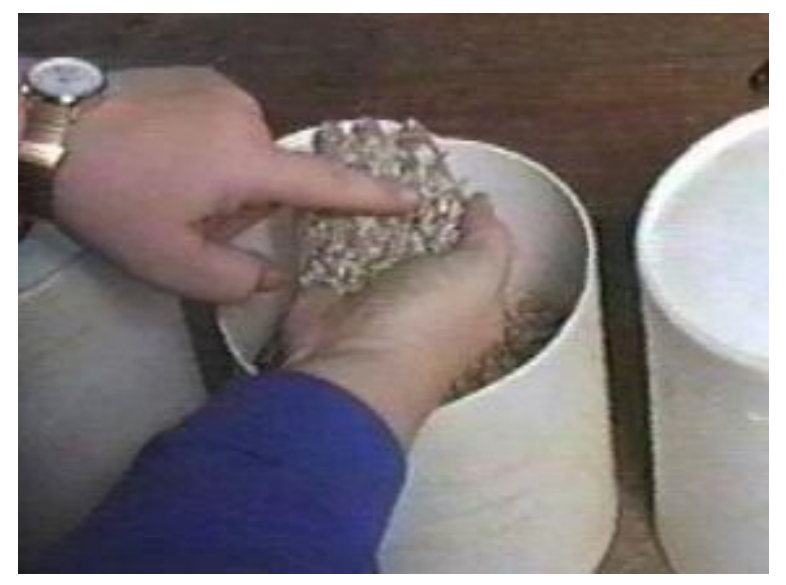


Figure 13. Dried screening residue from DISC Site showing nodules larger and lighter colored than those from Stonehenge Site.

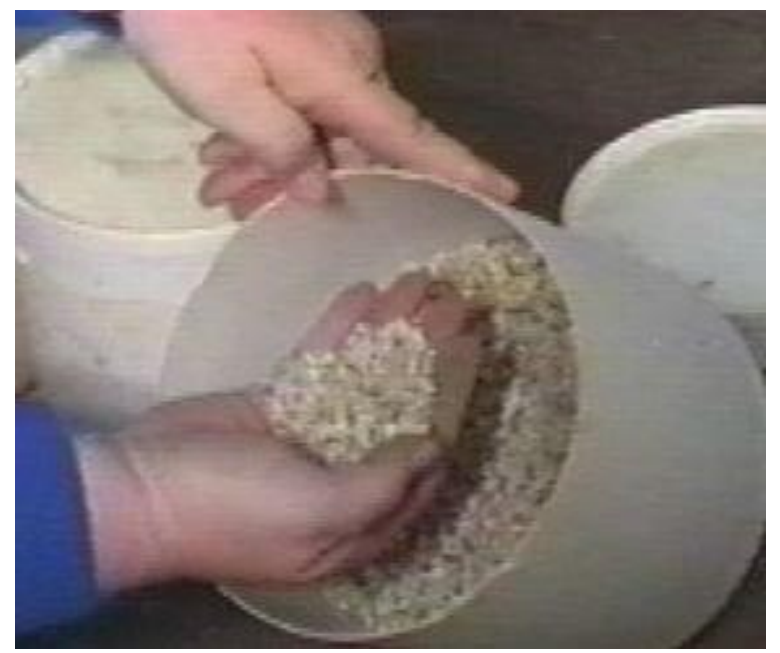


Figure 14. Dr. Ting in goggles and respirator, facial protective gear worn during handling of the glacial acetic acid.

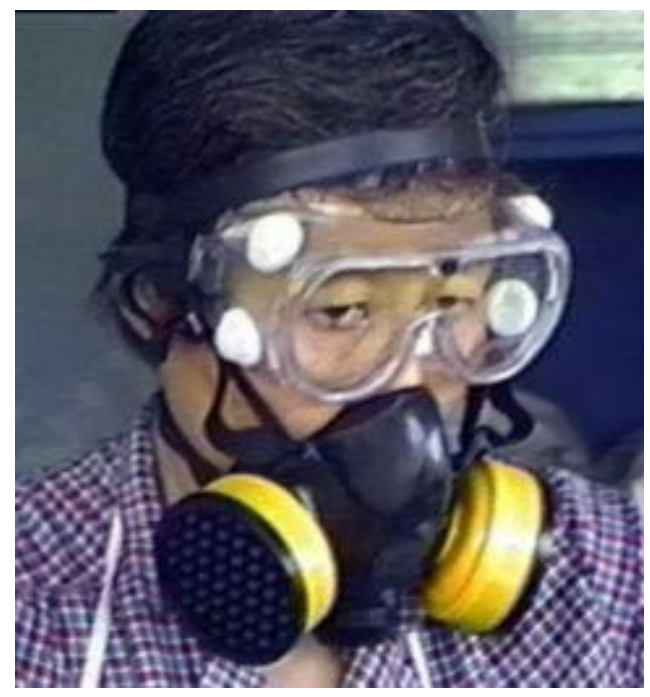


Figure 15. Dr. Ting and Casey Foote in protective gear are preparing to pump acid from the 55-gallon barrel for dilution to $10 \%$ and addition to the plastic boxes of rock. Rock saw in background is not used in this project.

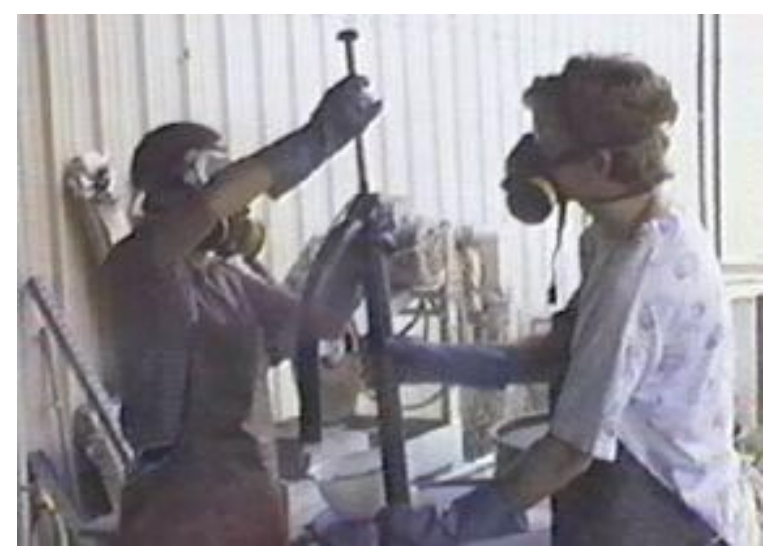


Figure 16. First lower molars of the rodent Copemys, illustrating mounting and numbering method used for microvertebrate fossils from the Miocene of Fort Polk. Gray clay holds the row of capsules in place.

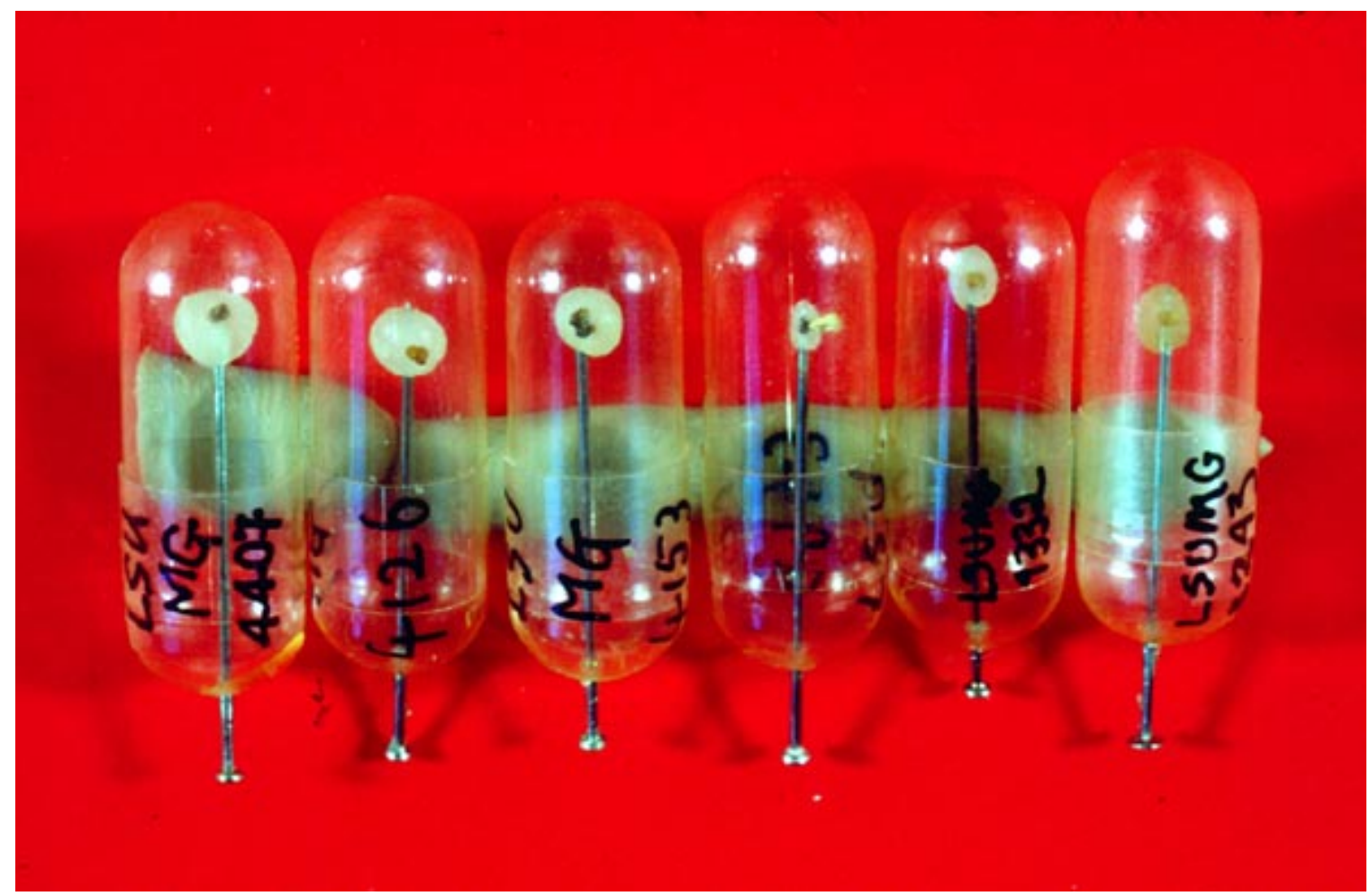


Figure 17. Judy's conglomerate, cross sectional view, Late Cretaceous, Aguja Formation, Big Bend National Park, Texas. Nodules and bone pieces show as white flecks. Photo by Julia Sankey.

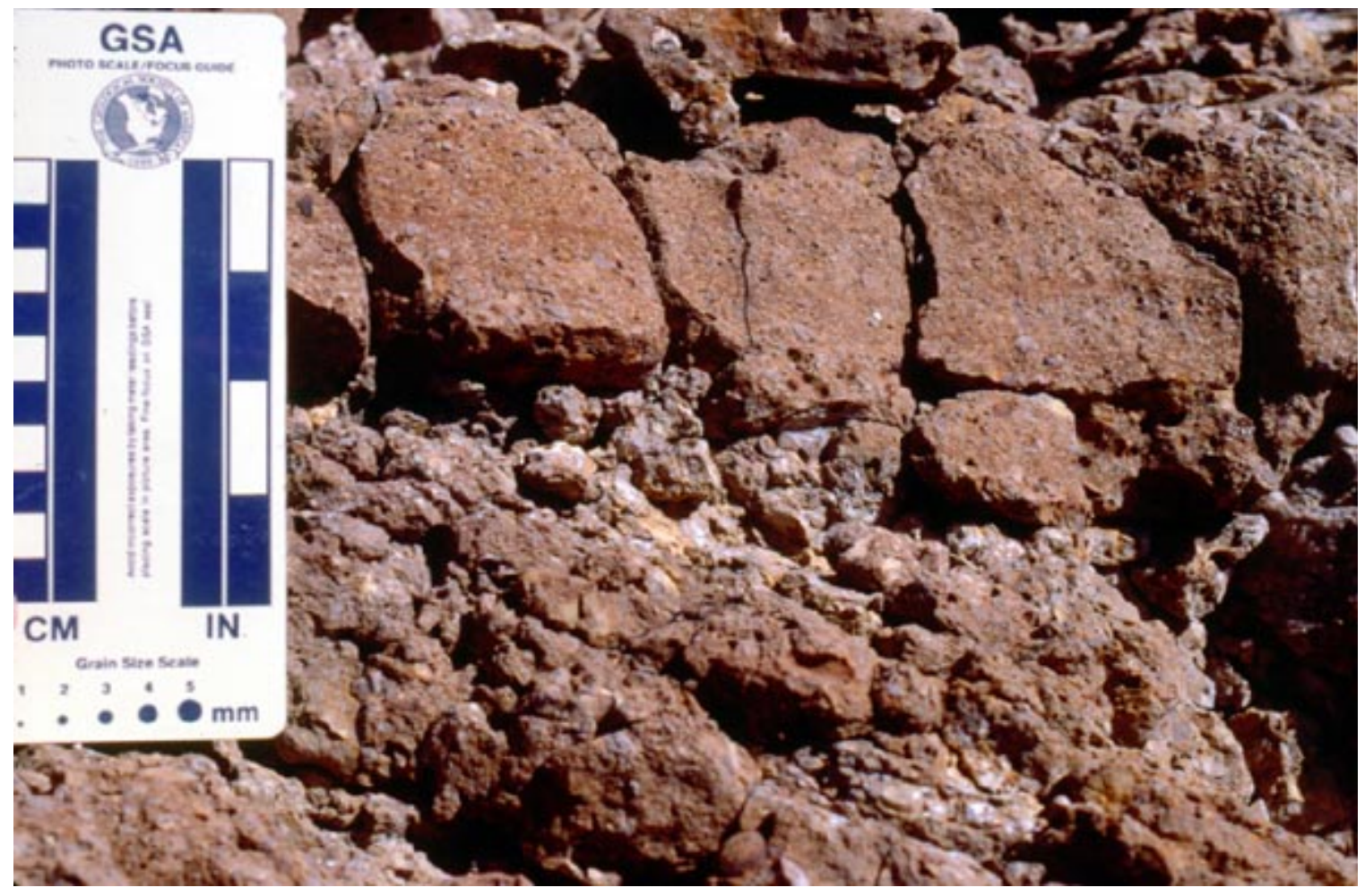


Figure 18. Dry $(L)$ and wet $(R)$ pieces of Julia's conglomerate from the Late Cretaceous, Aguja Formation, Big Bend National Park. Photo by Julia Sankey.

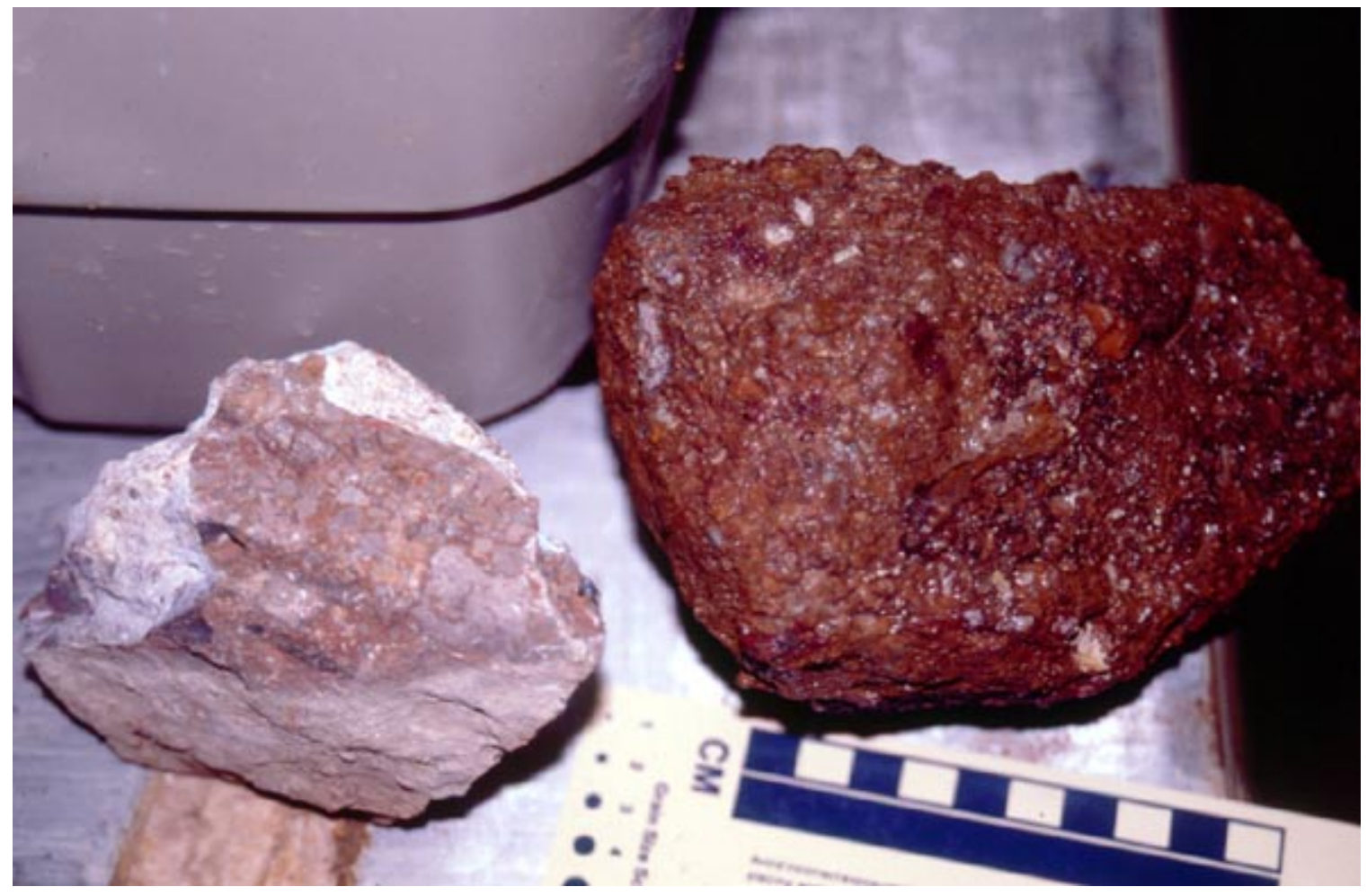


Figure 19. Weathered, man-made surface of the main conglomerate at DISC Site, Miocene of Fort Polk. It will be broken up with sledge or airless jackhammer and shoveled into bags.

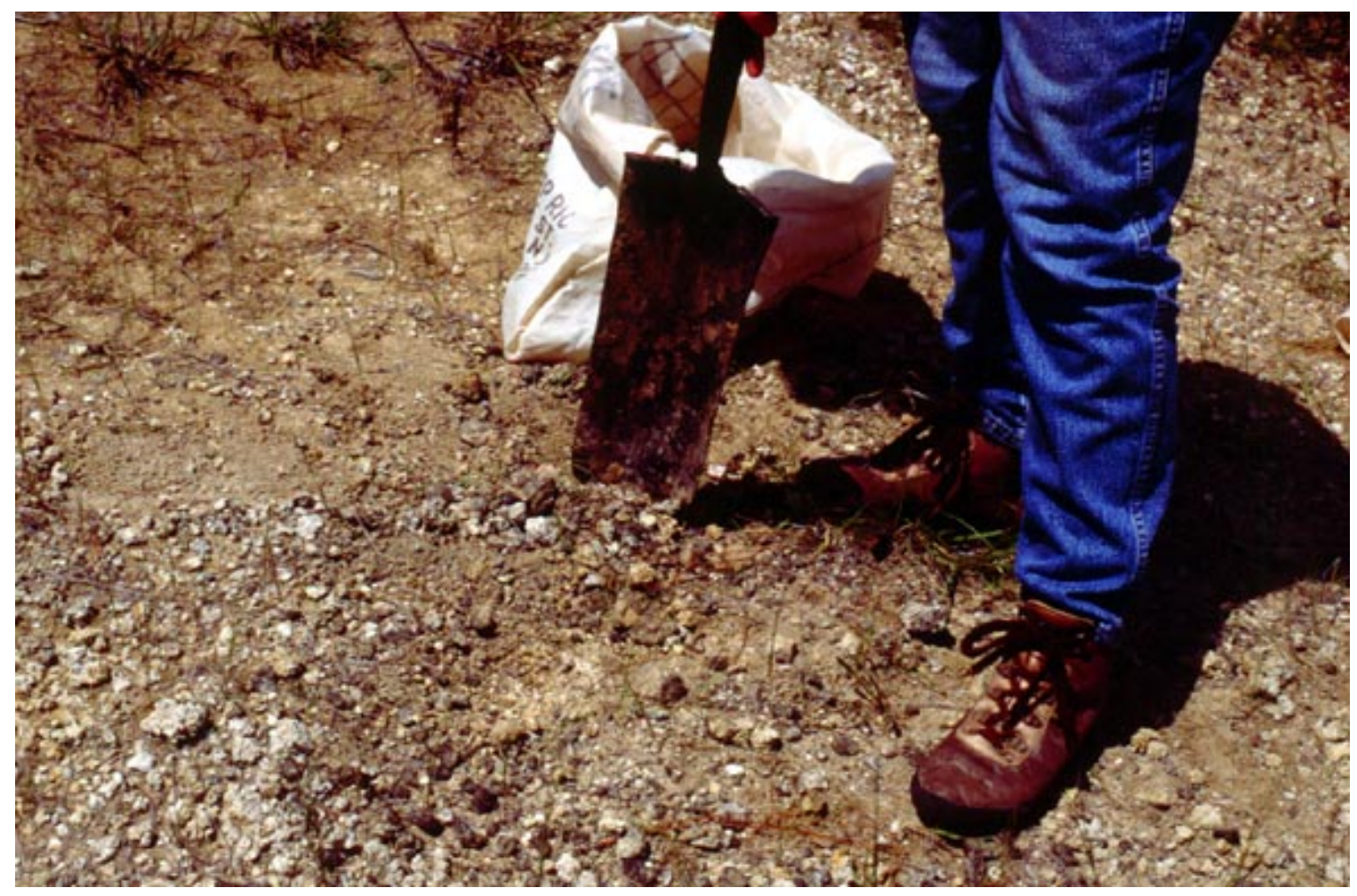


Figure 20. Incisor on weathered surface of the main DISC conglomerate.

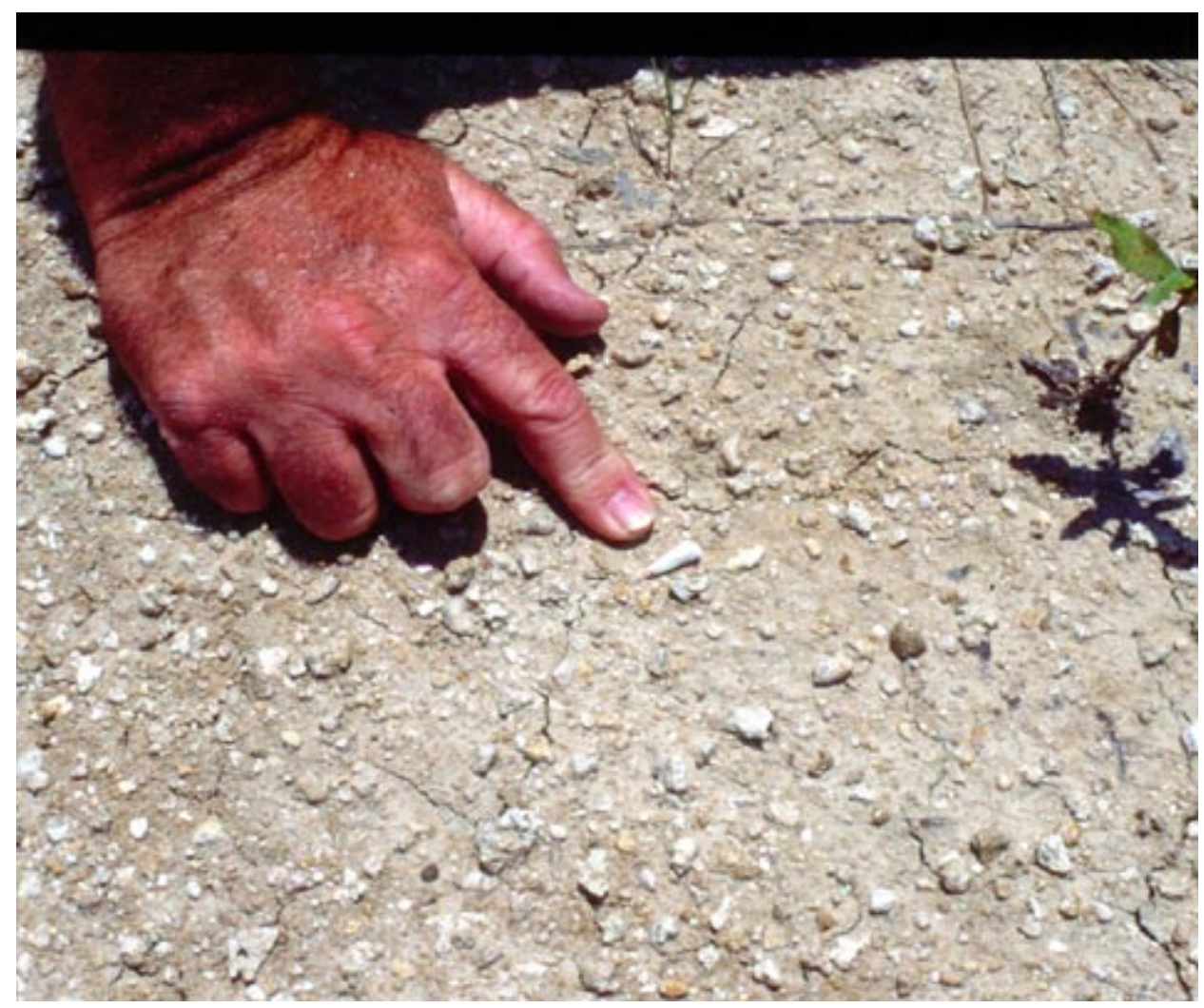


Figure 21. Cleaned cross sectional surface showing contact of main conglomerate from DISC site and underlying overbank mudstone.

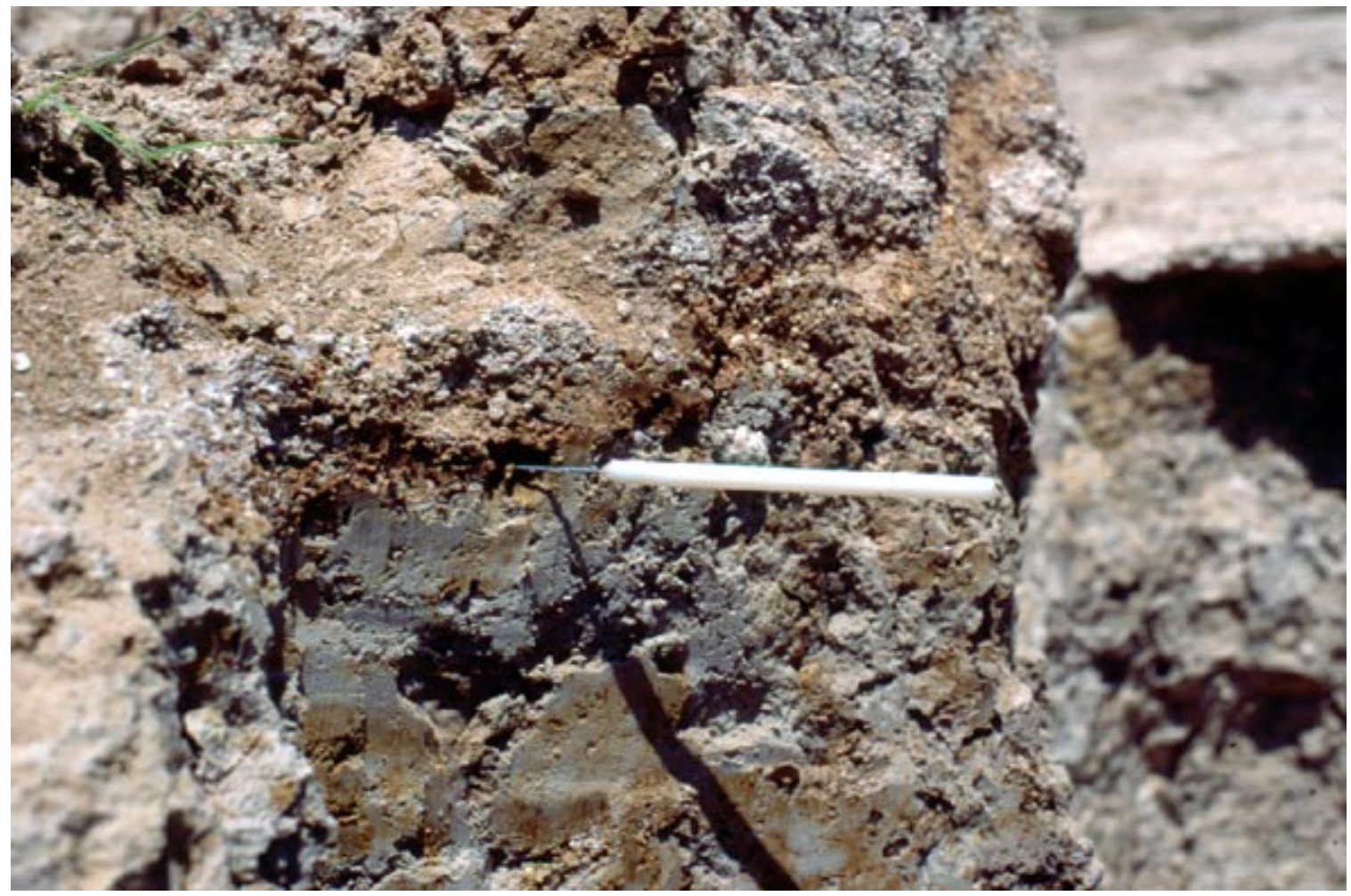


Figure 22. Erosion at DISC Site revealing several minor layers of pedogenic nodule conglomerate.

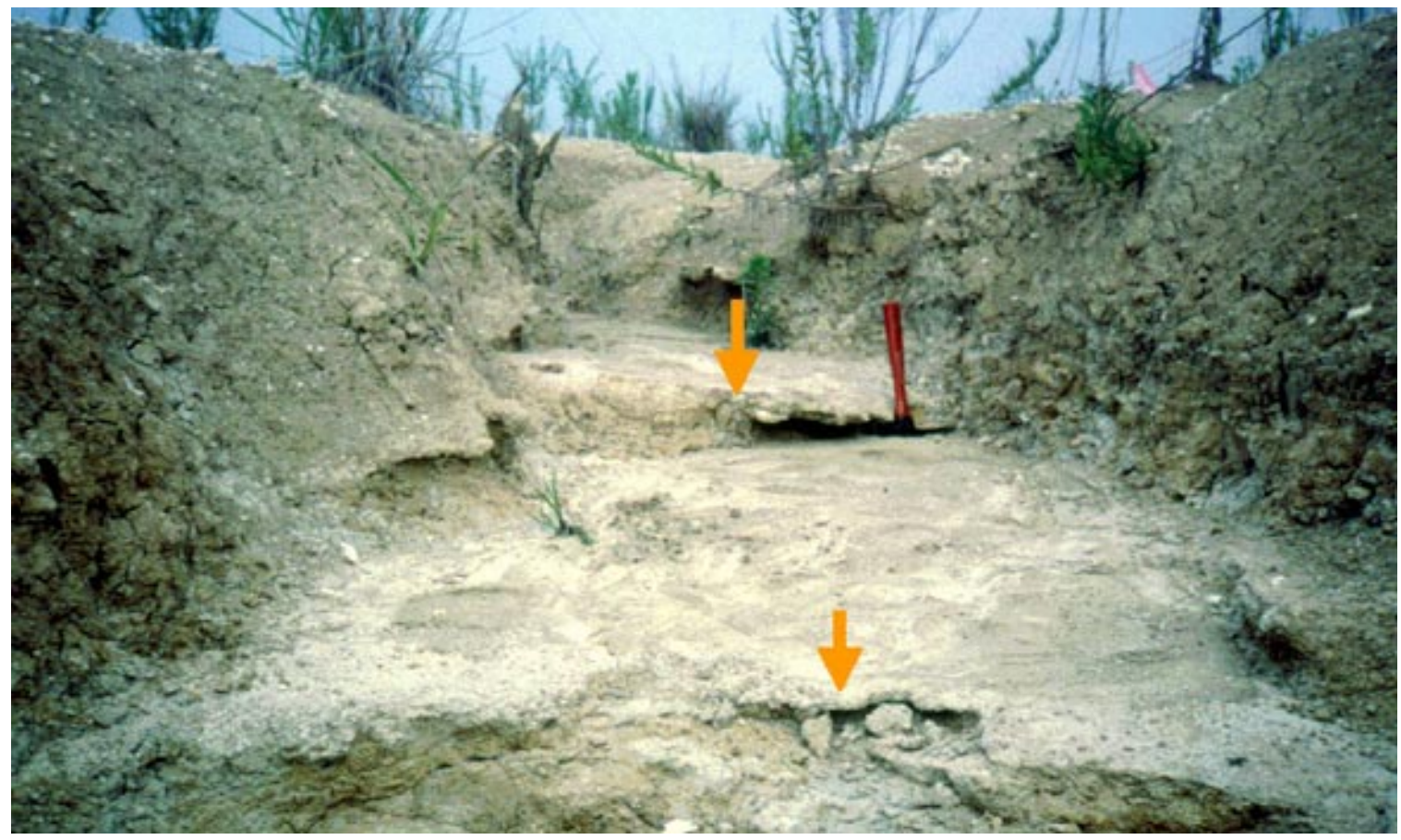


Figure 23. TVOR Site conglomerate, Miocene of Fort Polk, being photographed by geoarchaeologist Timothy Dalbey of the Corps of Engineers, Fort Worth District This is a color version of Figure 2 of Jones et al. (1996) and Photograph 8 of Schiebout (1997b). Site looks very similar to its appearance when first discovered.

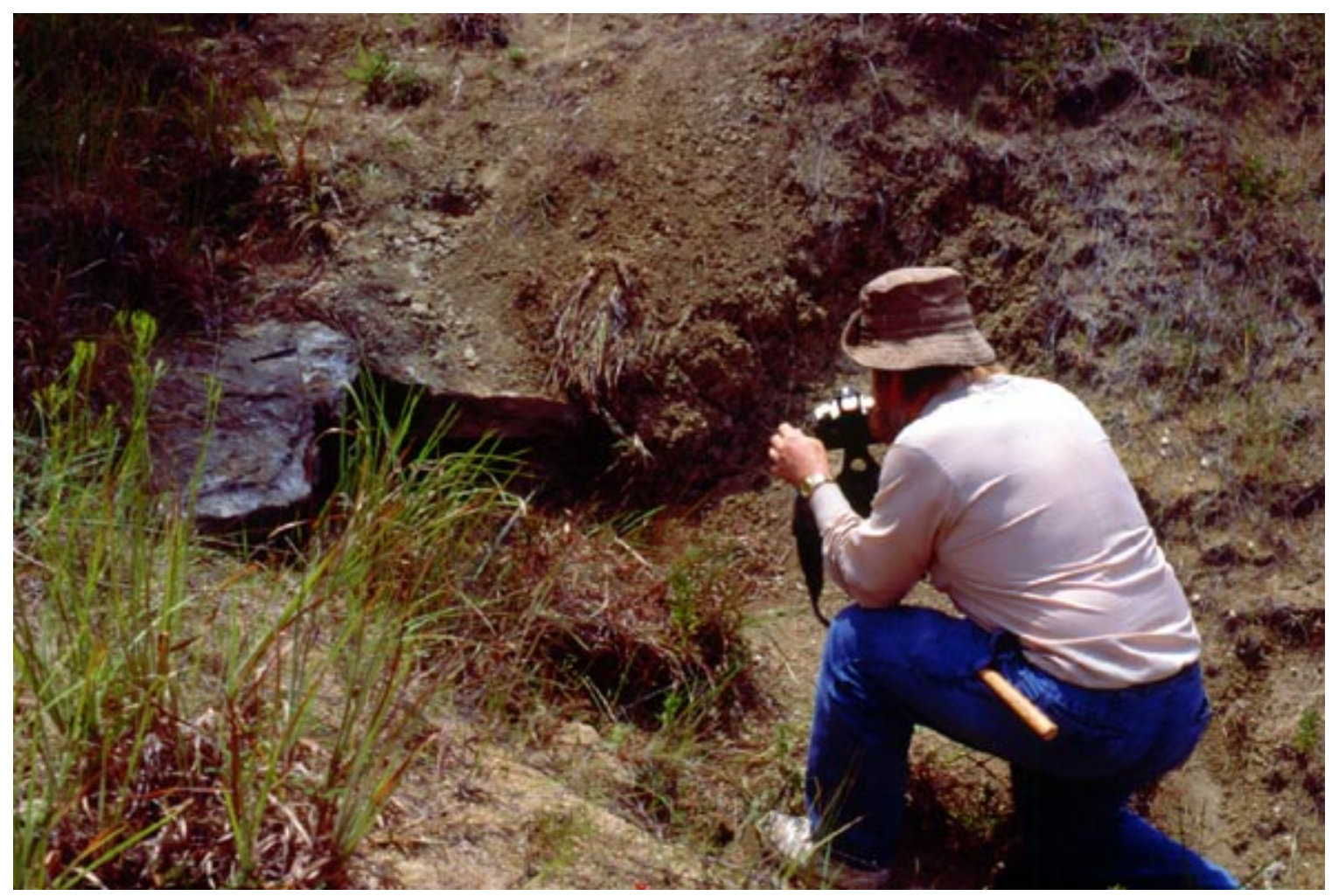


Figure 24. Close up, cross sectional view, of the conglomerate at TVOR Site showing both fresh dark surfaces which have been broken and lighter colored weathered surface. Cross bedding is evident.

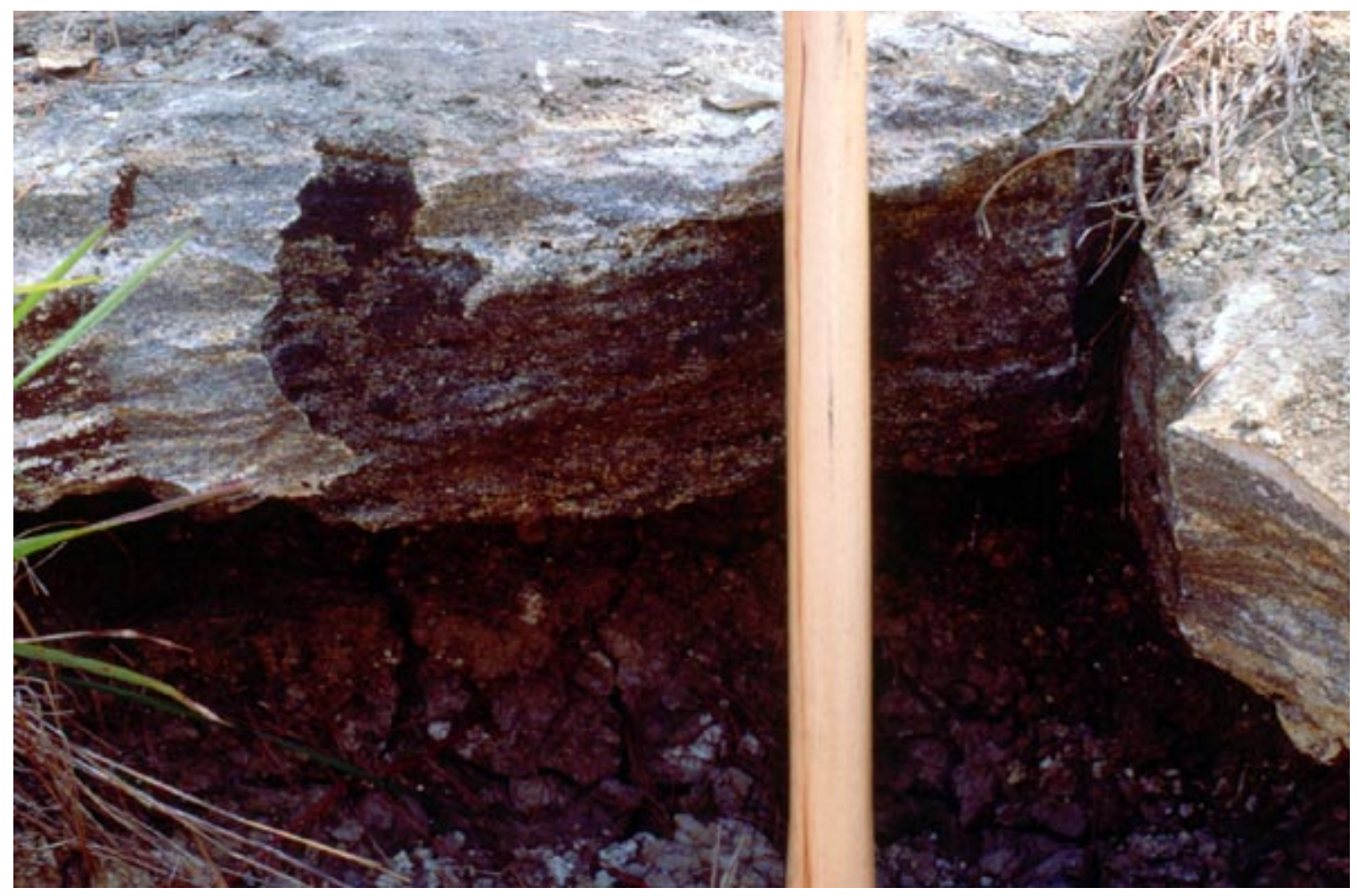


Figure 25. Thin section from lower part of DISC main conglomerate under polarized light. "A" indicates a nodule showing septarian cracks and "B" is a partially dissolved nodule. Scale $=1 \mathrm{~mm}$. This is a color version of Photograph 13 ( $\underline{\text { Schiebout 1997b) }}$. Photograph by Julitta Kirkova.

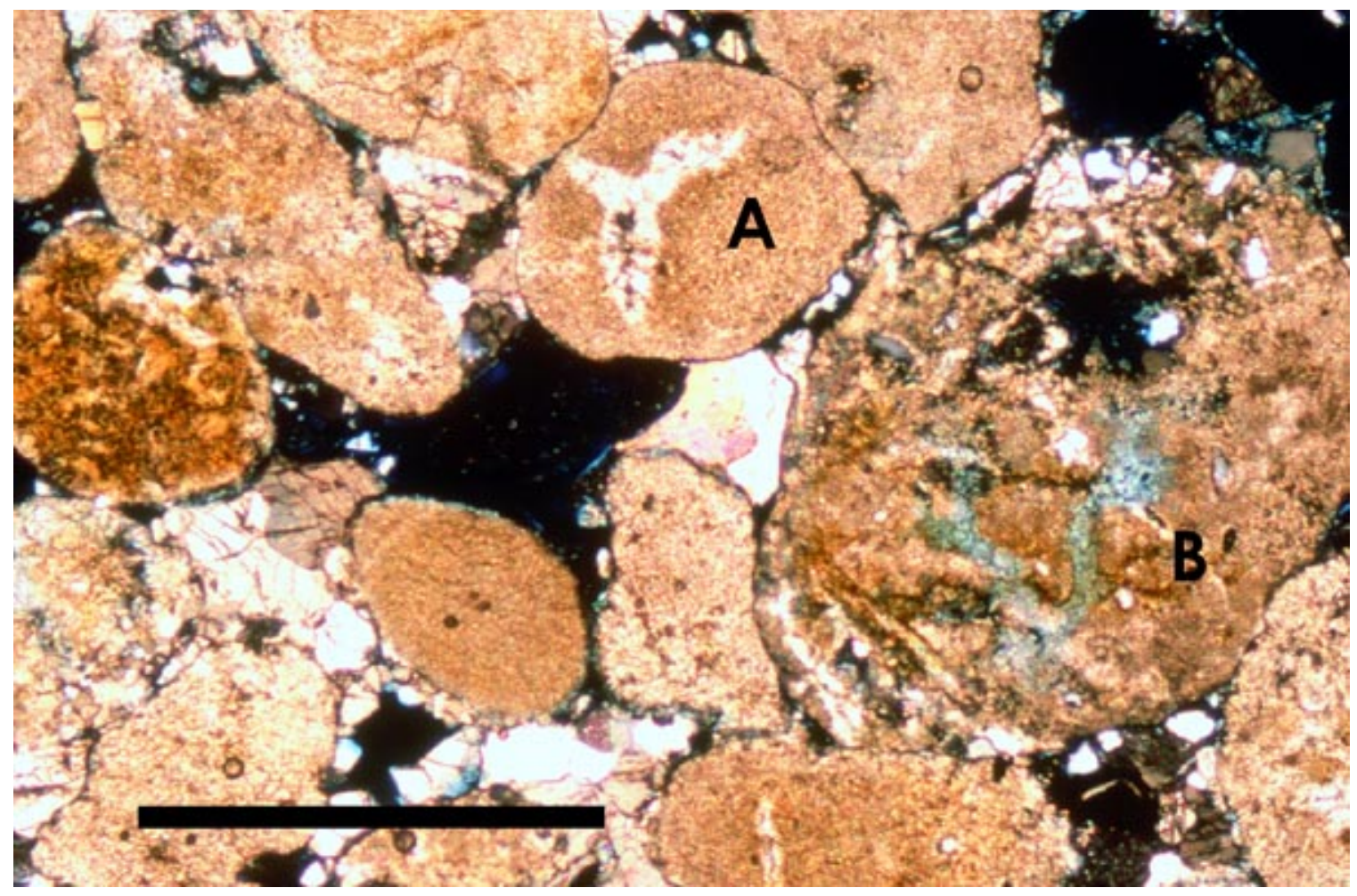


Figure 26. Thin section under polarized light, cut a few $\mathrm{cm}$ higher than Figure 25, from the upper part of the main conglomerate at DISC Site, showing more quartz sand. Scale $=1 \mathrm{~mm}$. Photograph by Julitta Kirkova.

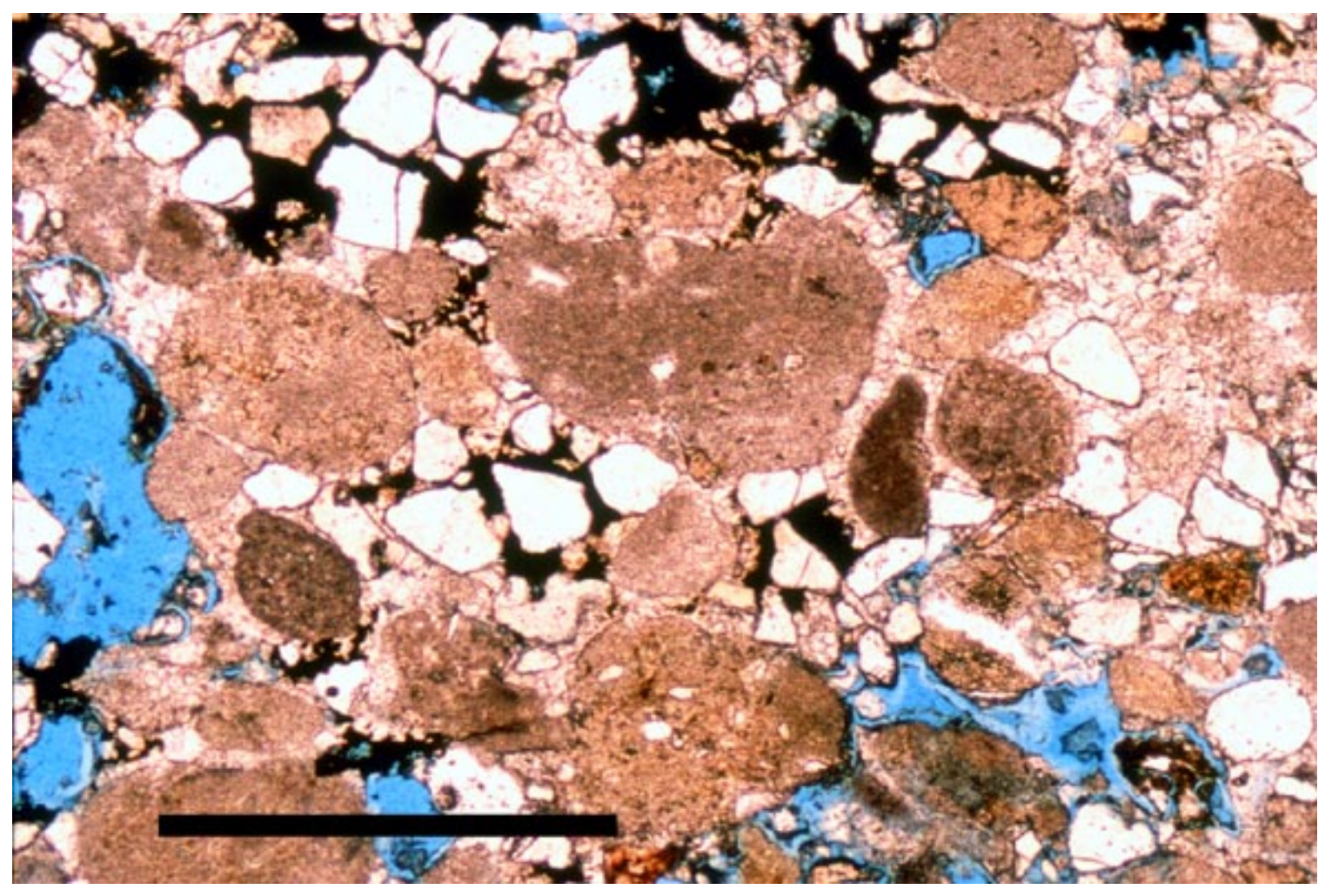


Figure 27. TVOR Site conglomerate under polarized light, showing rounded nodules and sand in a calcite cement. "A" indicates a nodule and "B" is a quartz grain. Scale = $1 \mathrm{~mm}$. This is a color version of Photograph 12 (Schiebout 1997b). Photograph by Julitta Kirkova.

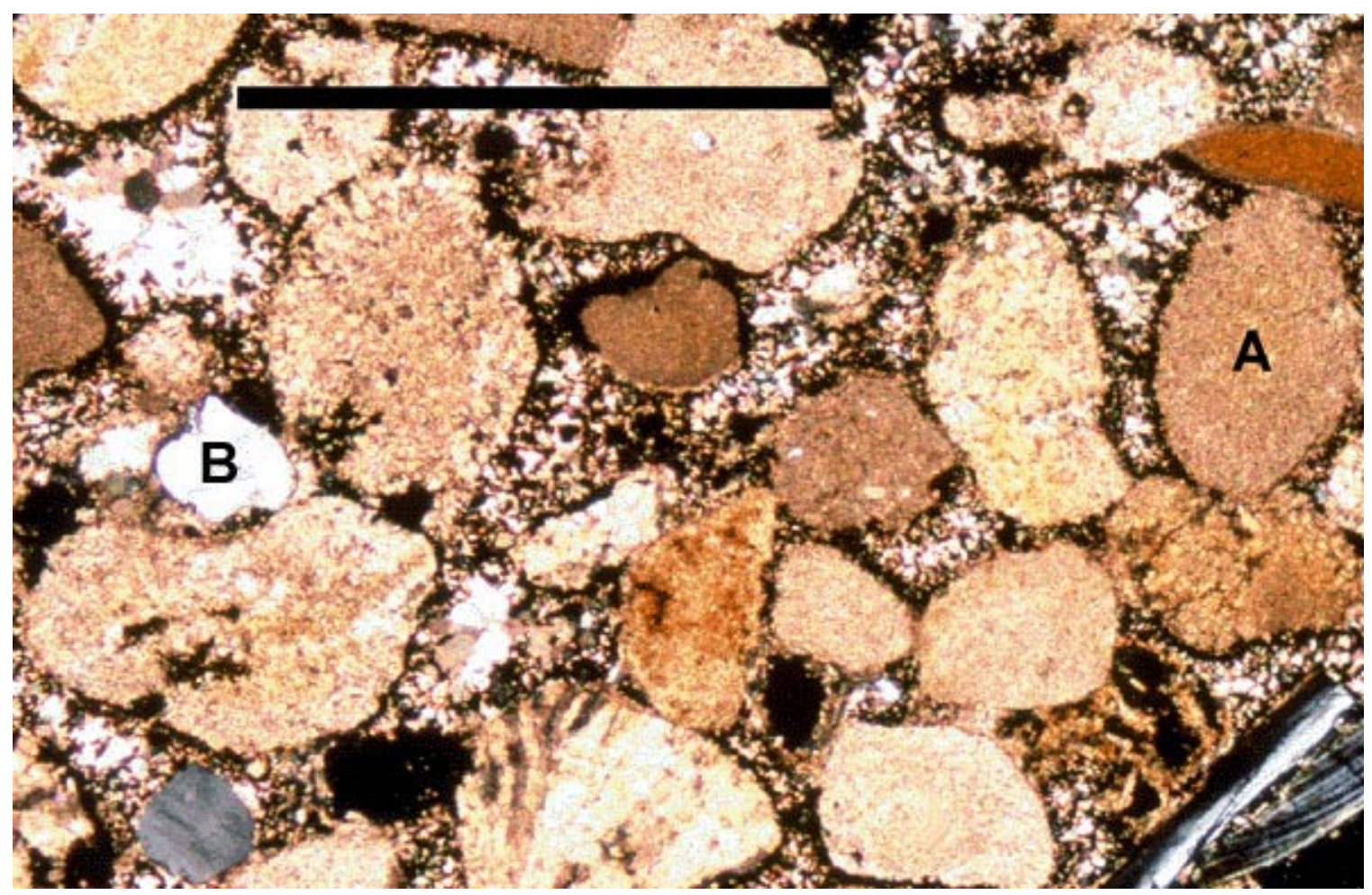


Figure 28. Sawed, cross sectional surface of a conglomerate boulder from a site near Coldspring, Texas at which mammals of the Miocene Cold Spring Local Fauna had been recovered.

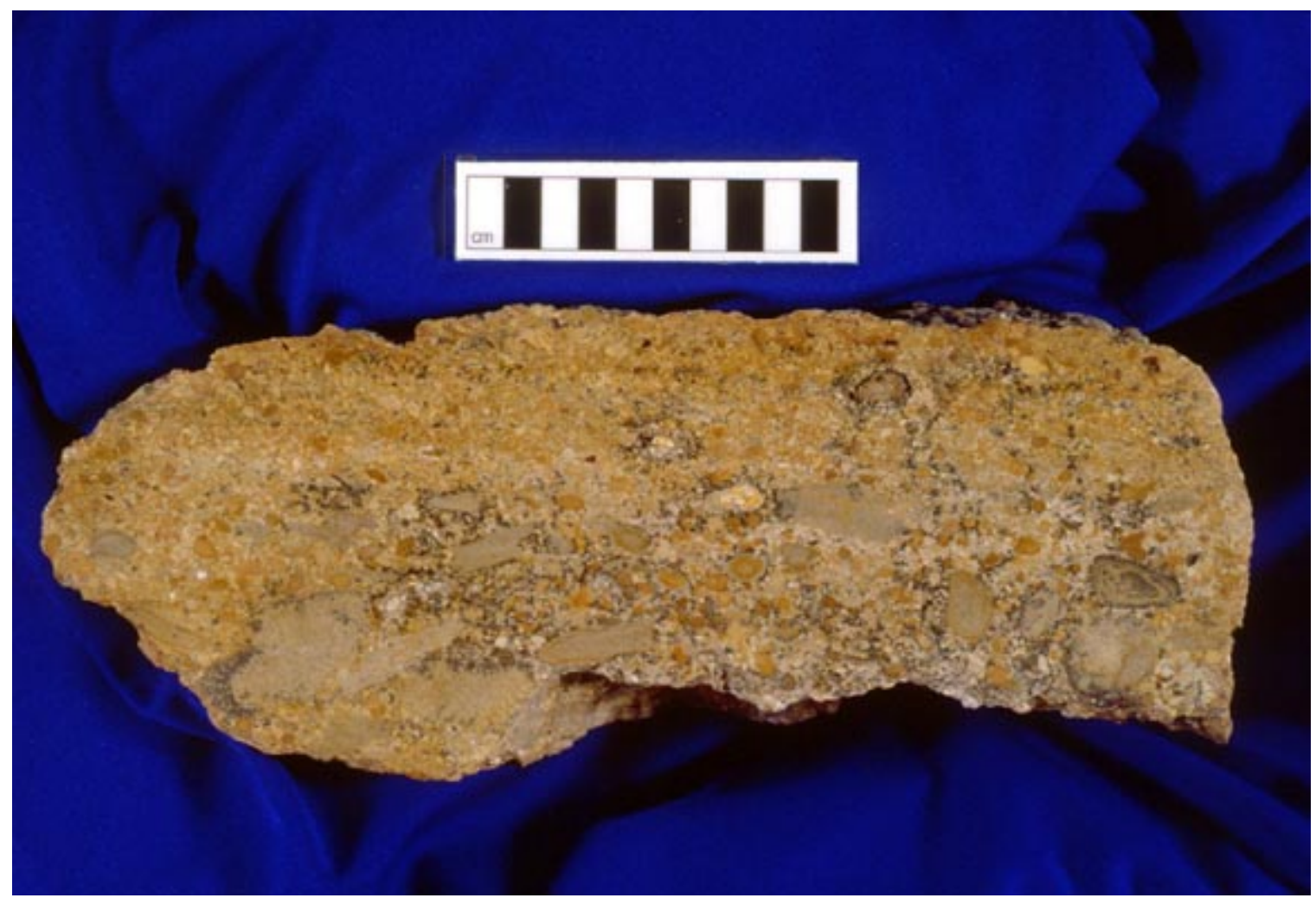


Figure 29. Erosional gully, TVOR S Site in the Miocene of Fort Polk, shows a pedogenic nodule conglomerate, indicated by an arrow. This site is a kilometer from TVOR. Photo by Megan Jones.

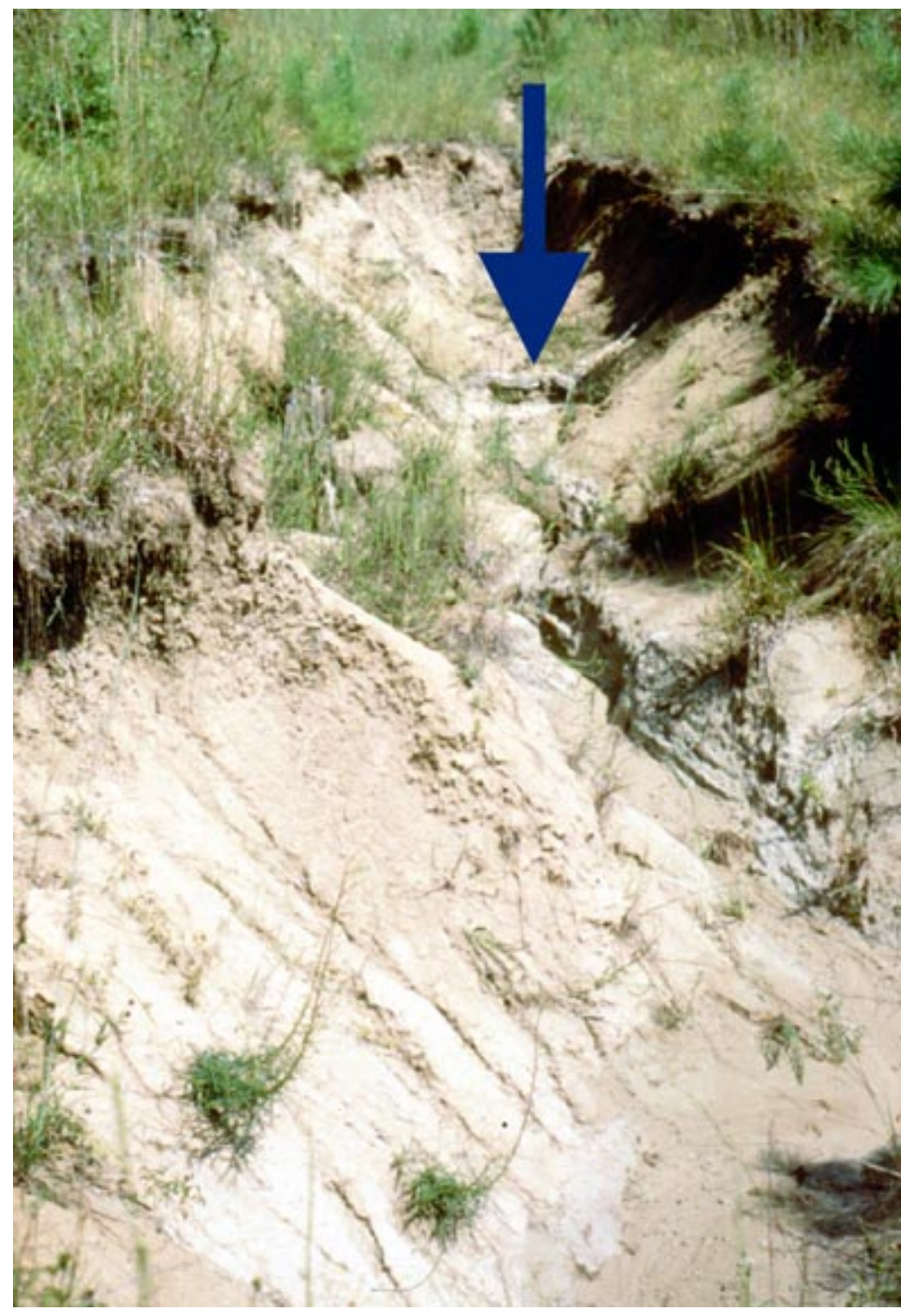


Figure 30. Close up of conglomerate seen in Figure 29. Photo by Megan Jones.

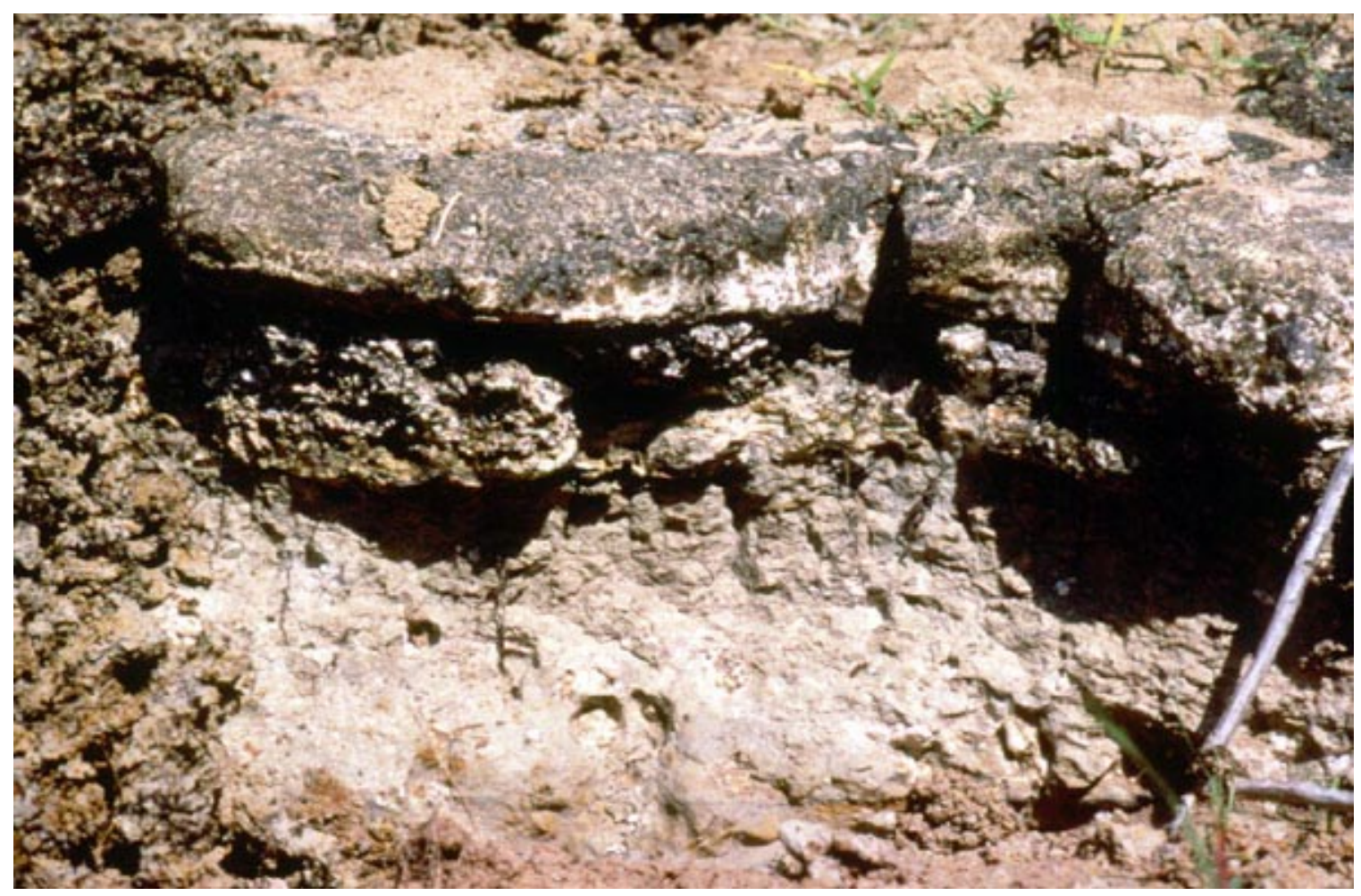


Figure 31. Nodule encrusted and cracked large mammal bone in place at Joe's Bonebed in mudstone of the Paleocene Black Peaks Formation in Big Bend National Park, Texas.

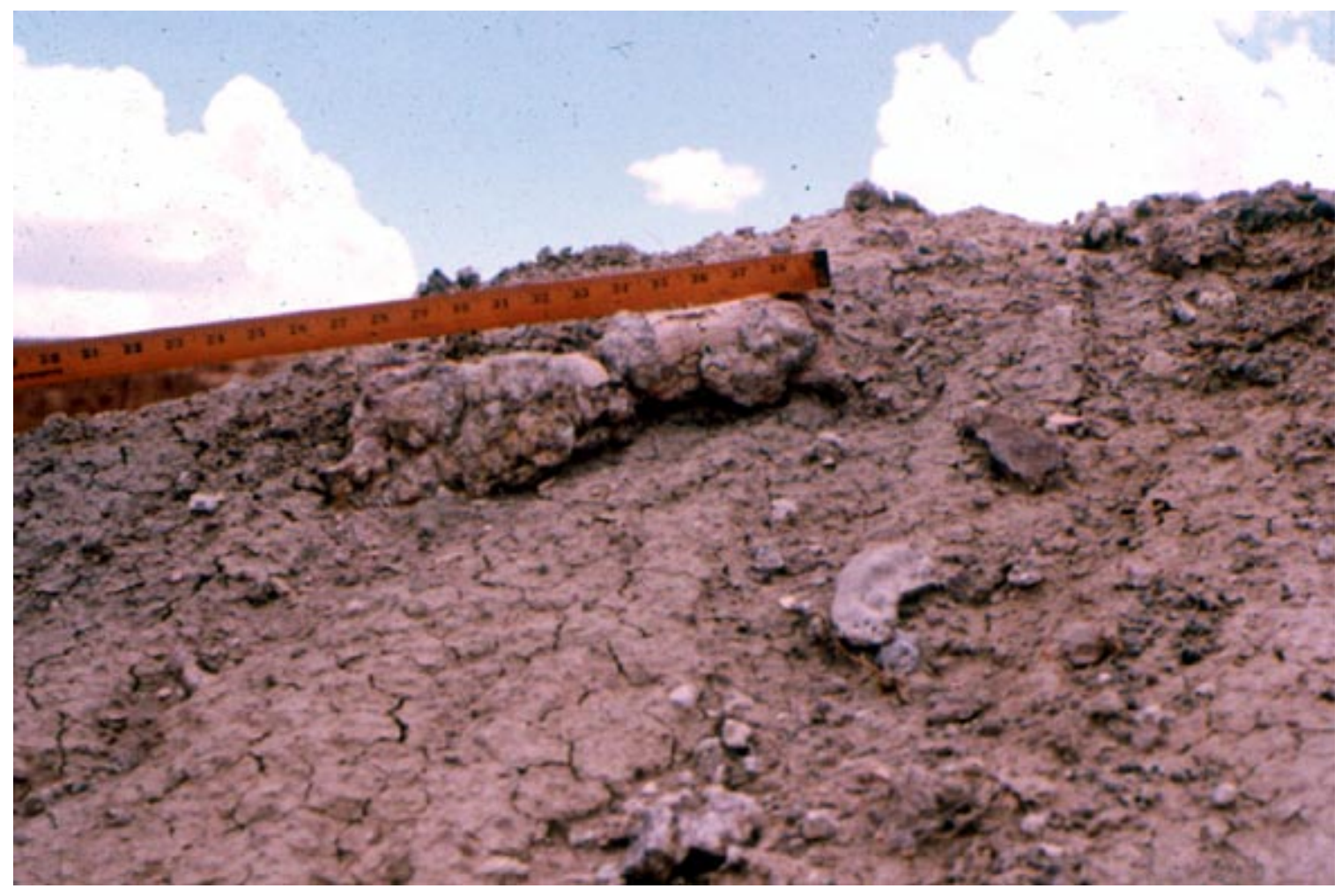


Figure 32. Mandible of Prosynthetoceras francisi exposed by weathering of a manmade surface at DISC Site. Displacement of the piece of the mandible from the rest may have resulted from the passage of heavy machinery over the site. An arrow indicates the displaced piece.

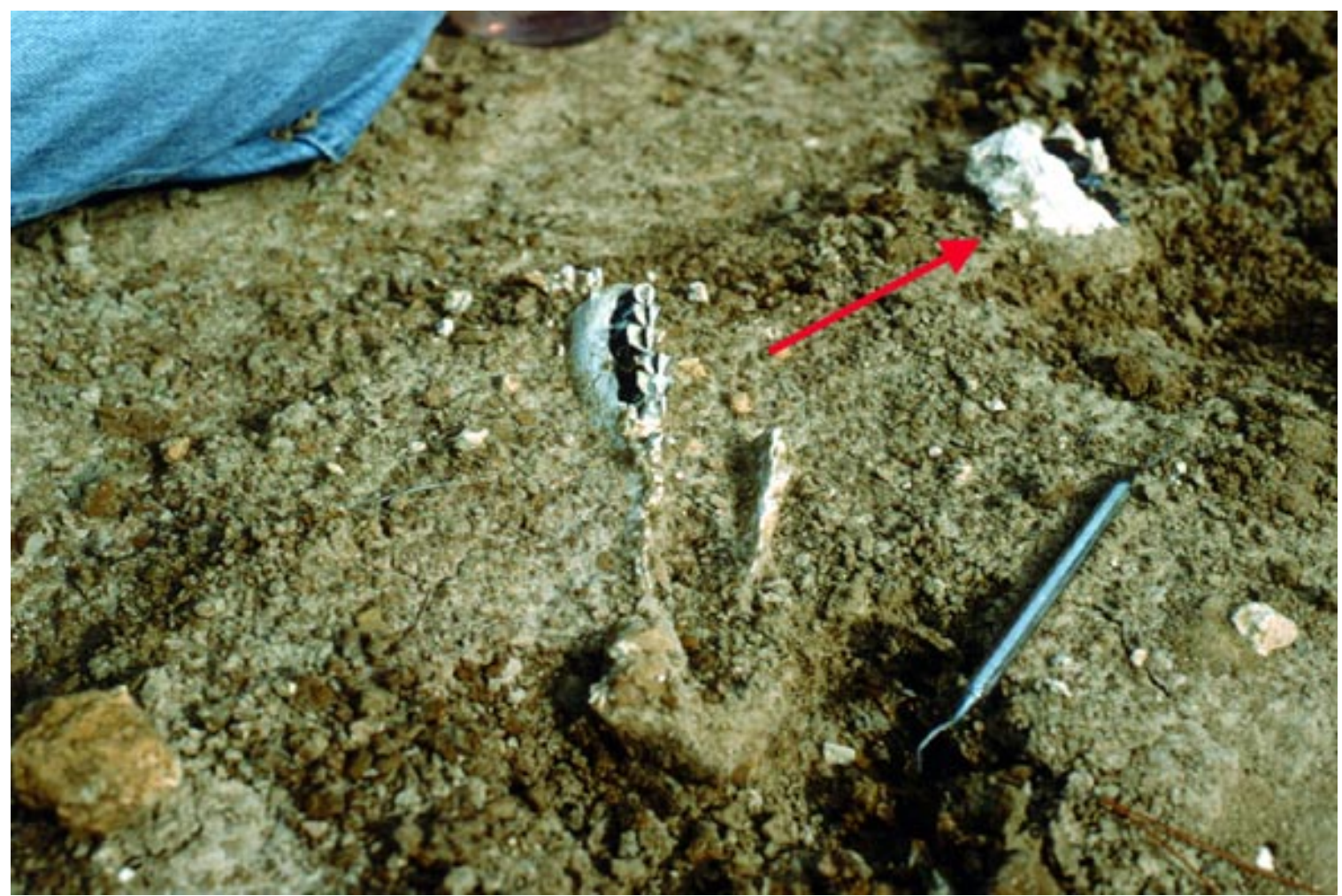


Figure 33. All fossils from a preliminary picking of the main conglomerate at DISC Site, Miocene of Fort Polk. Teeth and identifiable bone will be removed in a second picking. This is a color version of Photograph 16 (织hiebout 1997b).

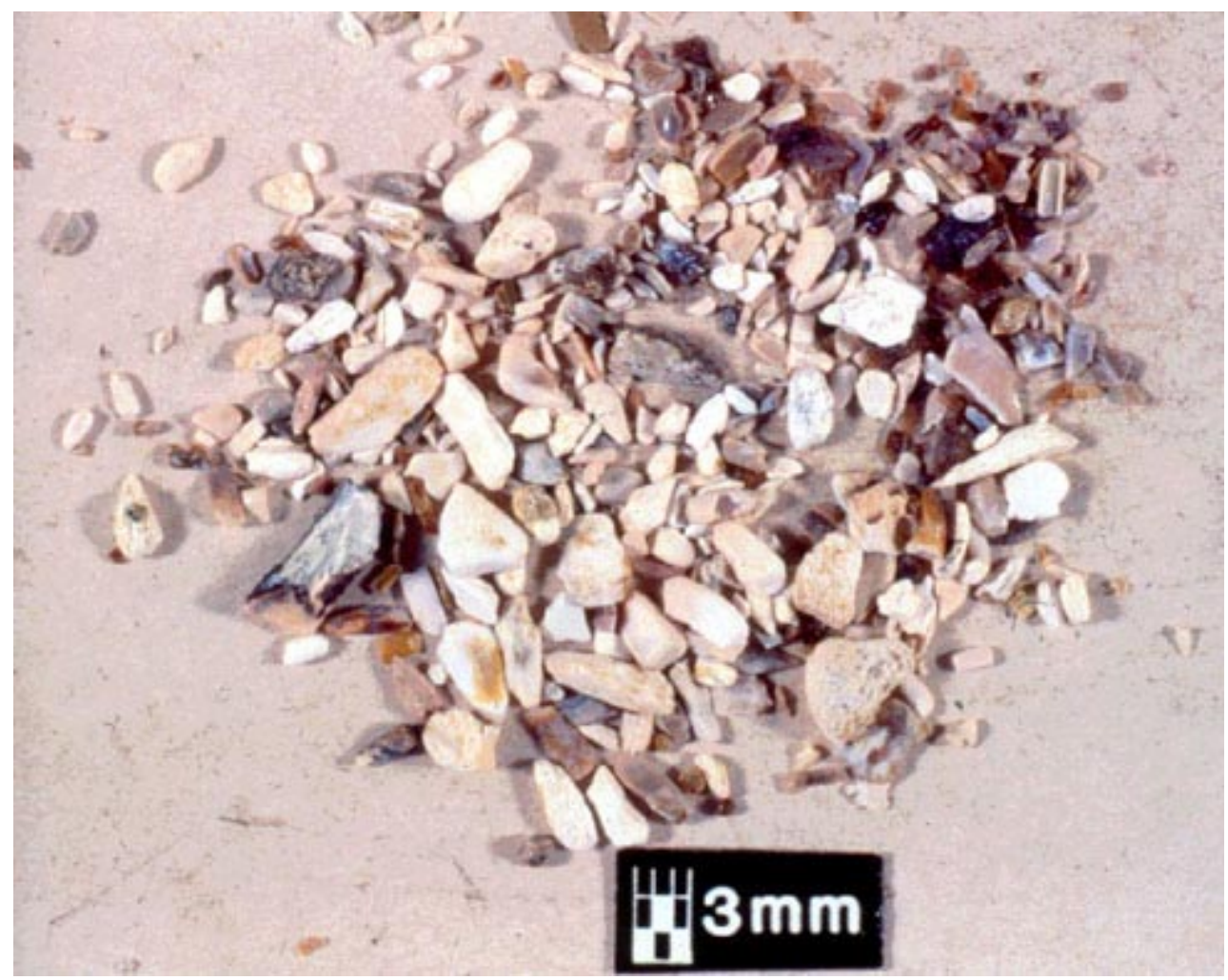


Figure 34. All mammal teeth from a session of picking at TVOR Site. A geomyoid rodent tooth is indicated by the arrow.

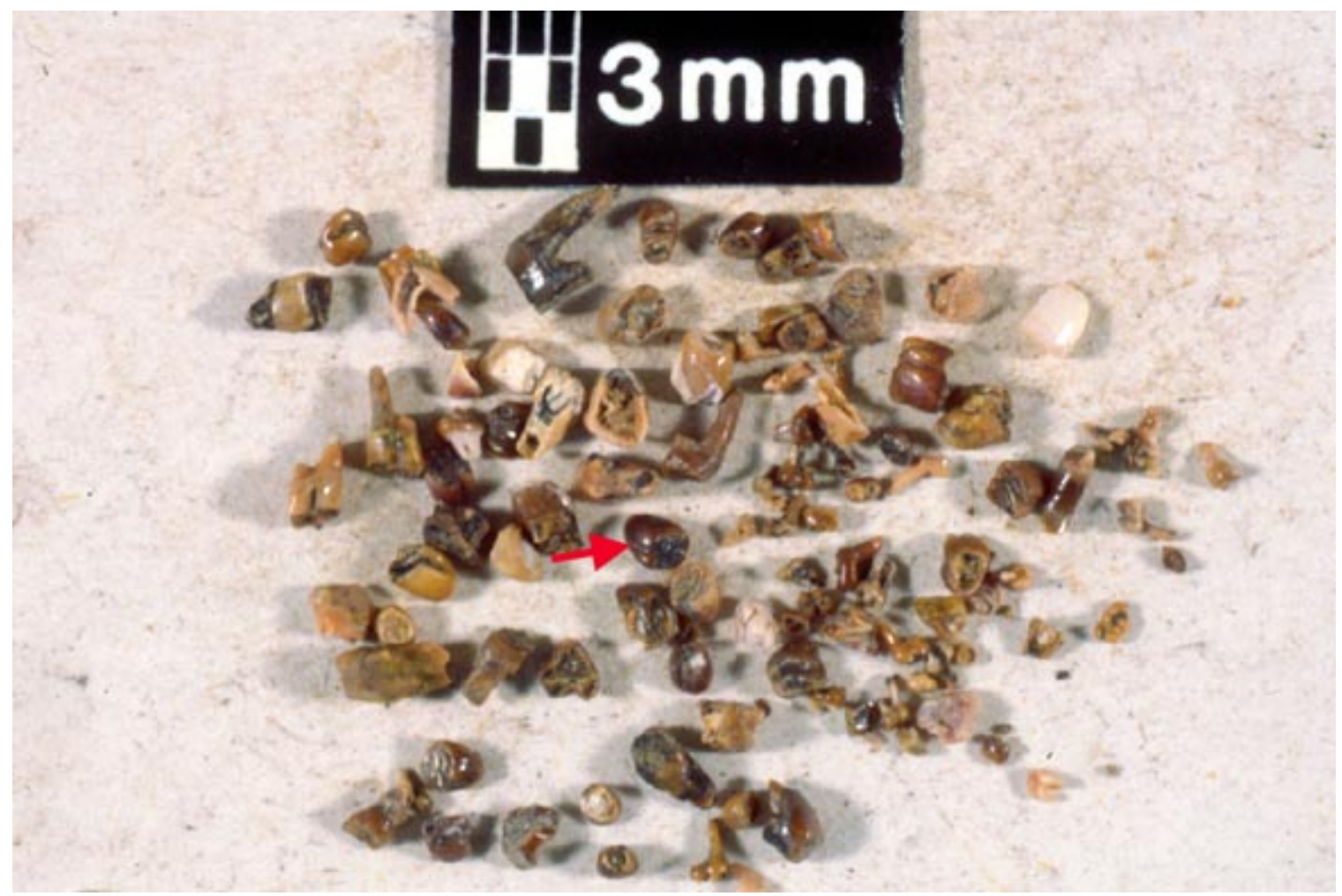


Figure 35. 300-counts of kinds of fossils from TVOR Site (A, B, C) and DISC (D). Figure 35C is modified from figure 8 and 35D is modified from figure 7 of Schiebout (1997b).

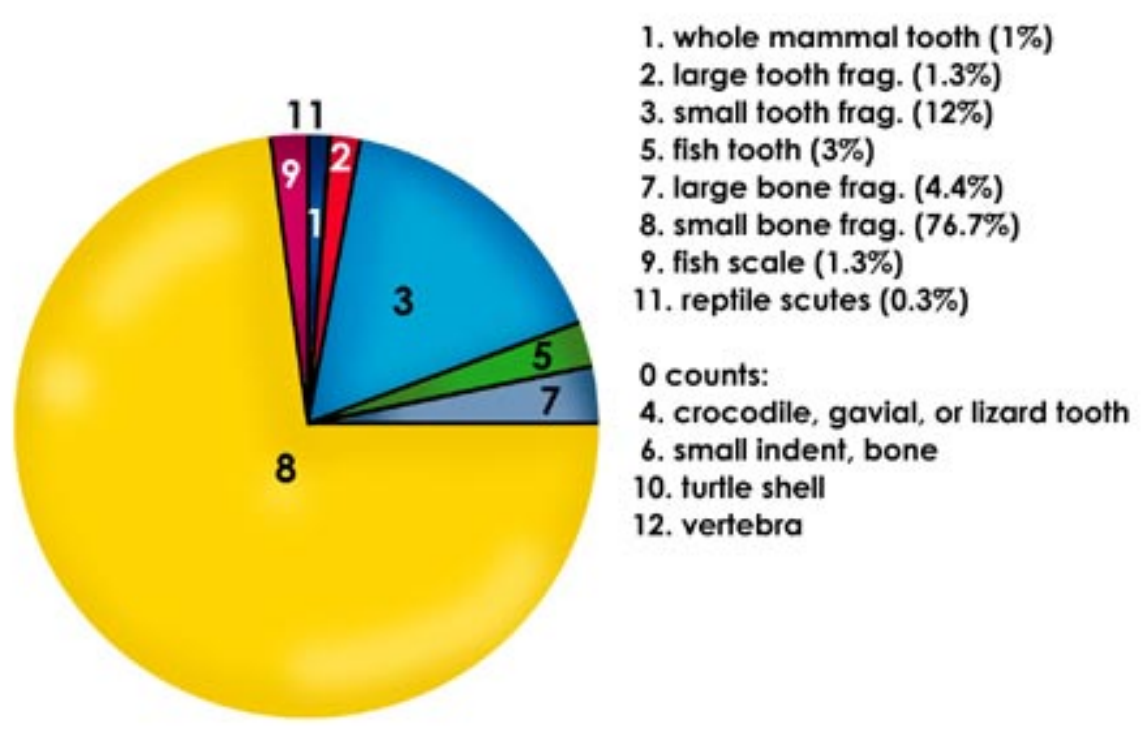

A 
1. whole mammal tooth $(0.4 \%)$

2. large tooth frag. $(2 \%)$

3. small tooth frag. $(9.3 \%)$

5. fish tooth frag. $(3 \%)$

7. large bone frag. $(9.3 \%)$

8. small bone frag. $(75 \%)$

9. fish scale ( $1 \%)$

\section{0 counts:}

8

4. crocodile, gavial, or lizard tooth

6. small indent, bone

10. turtle shell

11. reptile scutes

12. vertebra

\section{B}

1. whole mammal tooth $(0.3 \%)$

2. large tooth frag. ( $3 \%)$

3. small tooth frag. ( $4.3 \%)$

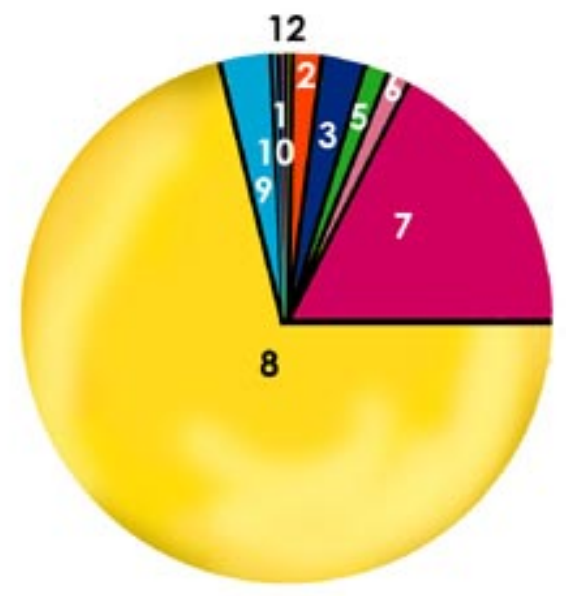

5. fish footh (1.7\%)

6. small indent, bone (1\%)

7. large bone frag. $(14.7 \%)$

8. small bone frag. ( $71.3 \%)$

9. fish scale $(2.7 \%)$

10 . turtle shell $(0.7 \%)$

12. vertebra $(0.3 \%)$

0 counts:

4. crocodile, gavial, or lizard tooth

11. reptile scutes

C 


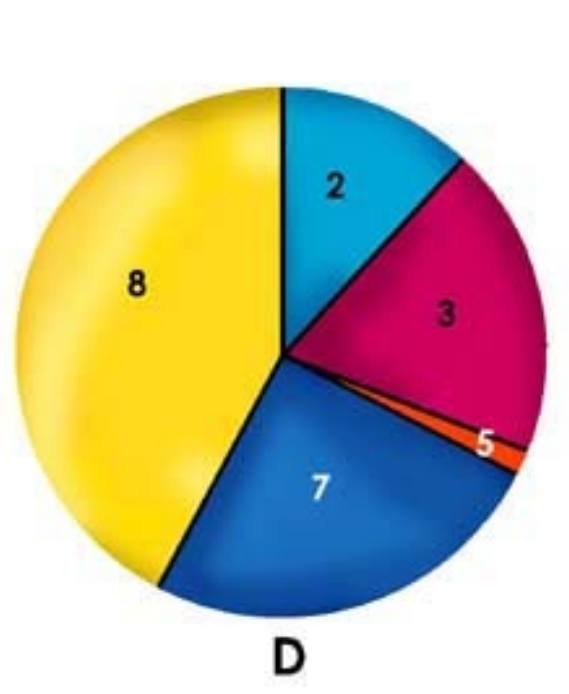

2. large tooth frag. (15\%)

3. small tooth frag. (21\%)

5. fish tooth (1\%)

7. large bone frag. (23\%)

8. small bone frag. ( $40 \%)$

0 counts:

1. whole mammal tooth

4. crocodile, gavial, or lizard tooth

6. small indent, bone

9. fish scale

10. turtle shell

11. reptile scutes

12. vertebra 
Figure 36. Bivariate plot of length versus width of the first lower molars of the rodent Copemys from sites on Fort Polk, Louisiana and from Coldspring, Texas. Three sites on Fort Polk, Stonehenge, Gully, and DISC, crop out in ascending stratigraphic order, and TVOR is probably stratigraphically lower than Stonehenge, although lack of outcrops makes this uncertain. 


\section{Bivariate Plot of Length (AP) vs. Width (W) of $M_{1}$ of Copemys from sites at Fort Polk, LA and from Coldspring, $\mathrm{TX}$}
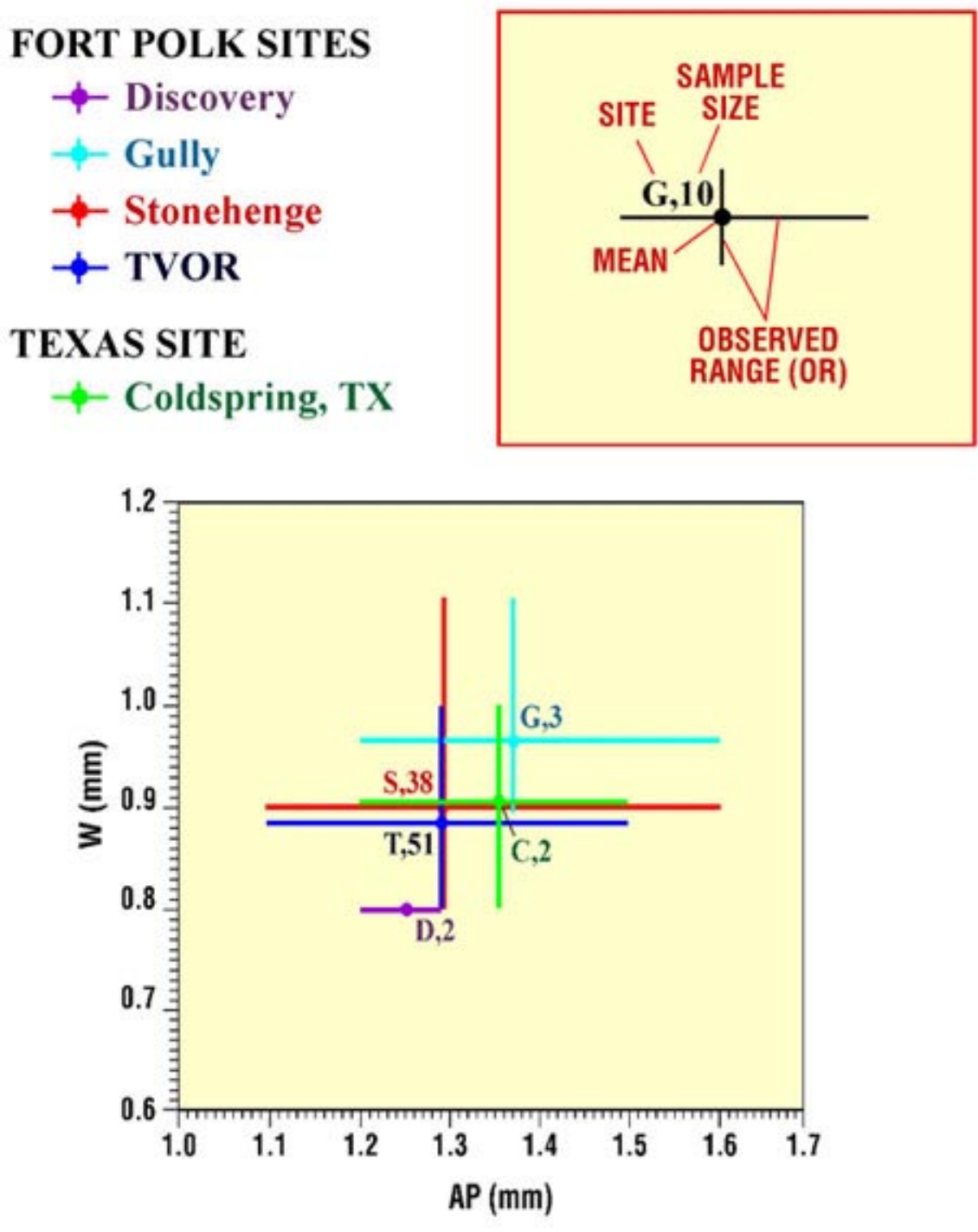
Table 1. Fish teeth and mammal teeth per $100 \mathrm{~kg}$. of rock processed at three sites on Fort Polk.

\section{TVOR}

Fish $/ 100 \mathrm{~kg}$.

Mammal/100 kg.
$1,396.7$

86.7
Stonehenge

550.0

62.8
DISC

42.8

8.6 
Movie 1. Rock from Discovery Site in almost spent acid solution. A piece is extracted and rinsed to show the undissolved rock. Discovery Site rocks are high in clay compared to those from other Fort Polk Miocene sites. File size: $801 \mathrm{~KB}$.

Movie 2. Spent acid is bailed from the plastic boxes for removal to an 85-gallon barrel for neutralization, $\mathrm{pH}$ testing, and aeration before disgard. Boxes are then moved to a gurney for transport to the screening area. File size 1.1 MB.

Movie 3. Boxes containing rocks from Stonehenge Site, Fort Polk, Louisiana, which have spent a rotation in acid, are brought by gurney to the washing sink. Rocks are rinsed and set aside on the box lids. Rocks will be returned to the emptied boxes after screening of the residue, and the boxes returned to their spots in the ranks, for further dissolution. File size 867 KB.

Movie 4. The small amount of spent acid left in the boxes is bailed into the screens, and residue in the boxes is emptied into the screens. Most of the spent acid was previously removed by bailing before the boxes were transported and was carried to the waste barrel. Spent acid in the boxes was tested for $\mathrm{pH}$ at the sink, using $\mathrm{pH}$ strips which change color to indicate acid levels. File size 926 KB.

Movie 5. Washing of residue from the boxes on the nested screens. File size $471 \mathrm{~KB}$.

Movies of the LSU Museum of Natural Science bulk acid lab feature Dr. Suyin Ting, head of the lab, and student assistant Casey Foote. Lab procedures are illustrated using material from the Miocene of Fort Polk, Louisiana. Film was shot during a regular screening session on August 5, 1997. 